\title{
PARA EL SOSIEGO Y QUIETUD DEL REINO. EN TORNO A FELIPE II Y EL PODER ECLESIÁSTICO EN EL PORTUGAL DE FINALES DEL SIGLO XVI
}

por

\section{Federico Palomo}

Centro de Estudos de História Religiosa, Lisboa

RESUMEN: Las negociaciones con el brazo eclesiástico en las cortes de Tomar adquirieron contornos singulares que perseguian la conservación del aventajado statu quo de que gozaba la Iglesia portuguesa frente a su bomóloga castellana. Esta posición resultaba de las bases sobre las cuales, desde la segunda mitad del siglo XVI, se definieron las relaciones entre la Corona portuguesa y el poder eclesiástico, marcadas por la necesidad de configurar una política confesional católica, cuyos principios y elementos principales estaban ya establecidos a la llegada de Felipe II al trono portugués. Con la intención de esbozar algunos de los aspectos que orientaron la política del nuevo monarca con las jerarquías eclesiásticas y religiosas del reino, este estudio permite subrayar la adopción de estrategias que, si bien, por un lado, perseguian la eliminación de la oposición a la candidatura filipina proveniente de los grupos eclesiástico-religiosos, por otro, estuvieron marcadas por la continuidad en el desarrollo de lo que babian sido las líneas de fuerza establecidas con anterioridad a 1580.

PALABRAS ClAVE: Iglesia portuguesa. Unión Ibérica. Oposición política. Poder episcopal. Felipe II.

ABSTRACT: Negotiations with churchmen in the Cortes of Tomar focused on preserving the convenient status quo that Portuguese church retained, compared with the Spanish church. This position arose from the factors conditioning the relationship between the Portuguese crown and ecclesiastical power from the second balf of the sixteenth century, characterised by the need to define a Catholic confessional strategy. The main aims and metbods of this strategy were already established by the time Philip II became king in 1580. With the aim of outlining some elements of the religious policies of Philip II in Portugal, this paper - on the one hand - traces the implementation of strategies dealing with ecclesiastical opposition to Philip's accession. On the other band, it addresses continuity in the confessional guidelines defined before 1580.

Hispania, LXIV/1, núm. 216 (2004) 63-94 
KEY WORDS: Portuguese church. Union of Spain and Portugal. Ecclesiastical power. Philip II. Cortes.

Cuando la muerte sin descendencia del rey Sebastián I, en 1578, abrió el camino a Felipe II para hacer valer sus alegados derechos de sucesión al trono portugués, el monarca castellano, ciertamente, debió ser consciente no sólo de los recelos que en muchos suscitaba su candidatura, sino también de la complejidad que entrañaba incorporar a su Monarquía un reino como el portugués, cuya configuración política, a pesar de las semejanzas, distaba de ser idéntica a la de otros territorios peninsulares, habiendo sido objeto, por lo demás, de importantes transformaciones durante el gobierno de los últimos monarcas de la dinastía de Avís y, en particular, desde el reinado de Juan III. En otras palabras, además de la coyuntura específica creada por la crisis sucesoria, una arquitectura de poderes relativamente consolidada y definida distinguía este proceso político - haciéndolo más complicado- de experiencias semejantes, habidas en el pasado, en el seno de la Monarquía Hispánica.

En este sentido, es bien conocido que las negociaciones con el brazo eclesiástico, dentro del contexto de las Cortes de Tomar y de la definición del estatuto político que habría de determinar la integración de Portugal en la Monarquía de Felipe II, adquirieron contornos singulares que, frente al principio de equiparación con los privilegios castellanos que, en general, marcó el compromiso con la nobleza y el tercer estado, perseguían la conservación del aventajado statu quo de que gozaba la Iglesia portuguesa frente a su homóloga castella$\mathrm{na}^{1}$. Esta posición resultaba de las bases sobre las cuales, a lo largo del siglo $\mathrm{XVI}$, se definieron las relaciones entre la Corona portuguesa y el poder eclesiástico, las cuales, desde la segunda mitad de dicha centuria, se vieron marcadas por la necesidad de configurar una política confesional de signo católico, cuyos principios y elementos principales estaban ya establecidos a la llegada de Felipe II al trono portugués ${ }^{2}$. En realidad, aunque las pautas que orientaron las inicia-

1 BouZA, Fernando: Portugal en la Monarquía Hispánica (1580-1640). Felipe II, las Cortes de Tomar y la génesis del Portugal católico (tésis doctoral), vol. II, Madrid, Universidad Complutense, 1987, pp. 559-612.

2 En relación con el concepto historiográfico de «confesionalización», véanse, en particular, los trabajos de REINHARD, Wolfgang: "Confessionalizzazione forzata? Prolegomeni ad una teoria dell'età confessionale», Annali dell'Istituto storico italo-germanico in Trento, 8 (1982), pp. 13-37; id., «Disciplinamento sociale, confessionalizzazione, modernizzazione. Un discorso storiografico», en PRODI, Paolo ed., Disciplina dell'anima, disciplina del corpo e disciplina della società tra medioevo ed età moderna, Bolonia, Il Mulino, 1994, pp. 101-123; SCHILluNG, Heinz: «Confessionalization in the Empire: Religious and Societal Change in Germany Between 1555 and 1620», en id., Religion, Political Culture and the Emergency of Early Modern State. Essays in German and Dutch History, LeidenNueva York, E.J. Brill, 1992, pp. 205-245. Para una aproximación a la recepción de este concepto, así como de la idea de "disciplinamiento social», en la historiografía italiana e ibérica, nos permitimos remitir a PALOMO, Federico: «Disciplina christiana. Apuntes historiográficos en torno a la 
tivas de carácter religioso de los monarcas portugueses, en general, fueron semejantes a las que se observaron en otros territorios de la Europa católica y, en concreto, en la Monarquía Hispánica, dichas iniciativas y las propias bases sobre las que asentó la confesionalización católica en Portugal adquirieron algunos rasgos específicos, que conviene tener presentes a la hora de, como nos proponemos en las siguientes páginas, poder esbozar algunos de los elementos que caracterizaron la política religiosa de Felipe II en el reino recién incorporado a su monarquía ${ }^{3}$.

\section{LA IGLESIA PORTUGUESA Y LOS ÚlTIMOS MONARCAS DE LA DINASTÍA DE AVÍS}

Contrariamente a lo que ha sido una tendencia común en la historiografía española de la época moderna, sobre todo para el reinado de Felipe II, las relaciones entre el poder regio y la Iglesia no parecen haber constituido, en el caso de Portugal, un objeto de especial interés para los historiadores contemporáneos. Bien es verdad que una bibliografía, en general, anticuada y fragmentaria ha dado paso, en los últimos tiempos, a algunos trabajos que, a pesar de, en la mayoría de los casos, no abordar expresamente la cuestión, han contribuido a delinear un cuadro general, construido desde perspectivas historiográficas modernas, de lo que fue la articulación entre el poder político y el religioso en el Portugal del Antiguo Régimen. Se ha puesto así de relieve, por un lado, el peso que, dentro del campo político portugués, tuvieron los diferentes poderes conformadores del propio campo religioso; por otro, se ha subrayado la importancia del catolicismo, no sólo como un factor esencial de la propia identidad regnícola portuguesa, sino también como vector fundamental del ideario político de la monarquía lusitana, cuyo orden político, jurídico y social, por lo demás, asentaba sobre las bases teológicas de una renovada tradición escolástica, que tuvo en las universidades de Coímbra y Évora algunos de sus más insignes cultivadores ${ }^{4}$.

disciplina y el disciplinamiento social como categorías de la historia religiosa de la alta edad moderna», Cuadernos de Historia Moderna, 18 (1997), pp. 119-136.

$3 \mathrm{El}$ presente ensayo asienta fundamentalmente sobre la información recogida en documentación portuguesa. Un trabajo futuro en los fondos del Archivo General de Simancas y en el Archivo Segreto Vaticano, que no hemos tenido ocasión de consultar, permitirá matizar e, incluso, corregir algunas de las ideas que se articulan en este estudio.

4 En este sentido, cabe destacar, sobre todo, la síntesis de PAIVA, José Pedro: «A Igreja e o poder", en AZEVEDO, Carlos Moreira dir., História Religiosa de Portugal, vol. II, MARQUES, João Francisco y Gouveia, António Camōes, coords., Humanismos e Reformas, Lisboa, Círculo de Leitores, 2000, pp. 135-185. De este mismo autor, aunque centrado en el estudio de un caso particular, véase también, "As relações entre o Estado e a Igreja após a Restauração. A correspondência de D. João IV para o cabido da Sé de Évora», Revista de História das Ideias, 22 (2001), pp. 107-131. En relación con la presencia del pensamiento teológico de la Segunda Escolástica en la cultura política y en en el discurso y las representaciones del poder en el Portugal moderno, cabe destacar, entre otros, los trabajos de CARDIM, Pedro: «Religião e ordem social. Em torno dos fundamentos católicos 
Lo cierto es que, de forma semejante a lo ocurrido en otros territorios de la península Ibérica y siguiendo estrategias paralelas, las bases principales sobre las que asentaron durante gran parte de la época moderna las relaciones entre la Corona portuguesa y los diferentes grupos y niveles jerárquicos que articulaban las estructuras de poder eclesiástico y religioso dentro del reino, fueron en buena medida definidas desde finales del siglo xv y a lo largo de la centuria de 1500. Es en este período, de hecho, cuando se asiste a una progresiva intensificación de la intervención regia en los asuntos religiosos, siendo, en muchos casos, la principal promotora de las reformas que se llevaron a cabo dentro de las congregaciones regulares, así como entre el clero secular y, en concreto, entre el episcopado portugués. La mano del monarca se hizo sentir, en primer lugar, sobre las propias jerarquías eclesiásticas y religiosas, gracias a la capacidad de la Corona para, en la práctica, intervenir en los procesos de elección de los prelados y reformadores de algunas órdenes y, sobre todo, de los obispos, a pesar de las diferencias jurídicas (que no prácticas) existentes entre las prerrogativas que a este respecto tenían los reyes de Castilla y las que usufruían los monarcas portugueses sobre aquellas iglesias que no estaban sujetas al Padroado regio 5 . Éste fue, ciertamente, una pieza clave en la arquitectura del poder monárquico en Portugal, tanto en lo que al desarrollo y administración de su política imperial se refiere, como en el propio control de una parte importante de las instancias eclesiásticas del reino, cuya geografía diocesana adquiere, en los

\footnotetext{
do sistema político de Antigo Regime», Revista de História das Ideias, 22 (2001), pp. 133-174; id., 0 poder dos afectos. Ordem amorosa e dinâmica política no Portugal de Antigo Regime (tesis doctoral), Lisboa, Universidade Nova de Lisboa, 2000; HeSPANHA, António M. y XAVIER, Ângela Barreto: «A representação da sociedade e do poder», en MATTOSO, José ed. História de Portugal, vol. IV: HeSPANHA, António M. coord., O Antigo Regime, Lisboa, Estampa, 1993, pp. 121-145. En relación, por otro lado, con la recepción en el Portugal de los siglos XVI y XVII de las teorías «regalistas», véase TORGAL, Luís Reis: Idelologia política e teoria do Estado na Restauraşão, vols. I y II, Coímbra, Biblioteca Geral da Universidade, 1982, pp. 256-268 y 45-92, respectivamente.

5 Mientras en Castilla, el rey gozaba del derecho de designar ad praesentationem à los prelados diocesanos del reino, en Portugal, dicha designación se hacía en idénticos términos en el caso de las iglesias integradas en el Padroado portugués (las erigidas en los territorios ultramarinos y las sedes de Portalegre, Leiría, Miranda, Elvas, Madeira y Angra do Heroísmo). La elección de los prelados para las diócesis más ricas e importantes del reino (Lisboa, Évora, Braga, Coímbra y Oporto) se regía por un régimen de designación ad supplicationem, que, jurídicamente, dejaba algún margen de maniobra al pontífice, aunque, en la práctica, éste seguía generalmente las indicaciones al respecto del monarca portugués. Sobre esta cuestión, véase, ALMEIDA, Fortunato de: História da Igreja em Portugal [191021], tomo II, Lisboa-Oporto, Livraria Civilização, 1968, pp. 47-49. En relación con el Padroado portugués, cuyo análisis mereceria un trabajo desde perspectivas historiográficas nuevas, remitimos al estudio clásico de REGO, António da Silva: $O$ Padroado Português do Oriente. Esboģo bistórico, Lisboa, Agência Geral das Colónias, 1940. Véase igualmente, aunque desde una perspectiva esencialmente canónica, JACQUES, Roland: De Castro Marim à Faïfo: Naissance et développement du padroado portugais d'Orient des origines à 1659, Lisboa, FCG, 1999; así como algunos de los estudios sobre la cuestión incluidos en Congresso Internacional de História. Missionação portuguesa e encontro de culturas. Actas, vol. III: Igreja, Sociedade e Missionação, Braga, UCP-CNCDP-FEC, 1993.
} 
años centrales del siglo XVI y bajo la mirada atenta del monarca, una nueva fisionomía, que permanecería inalterada hasta el siglo XVIII ${ }^{6}$. En todo caso, si el régimen de padroado constituyó un instrumento de especial importancia en el desarrollo de la política religiosa de la Corona portuguesa, ésa se articuló igualmente por medio no sólo de la creación, en 1536, de un tribunal del Santo Oficio, bajo moldes similares a los de la Inquisición española, como mediante la institución de un órgano consultivo, la Mesa da Consciência, erigido en 1532 con el objeto de dar resolución a las materias que tocaban a la «conciencia» del monarca. Integrada en la arquitectura burocrática regia, la Mesa fue, en la práctica, el instrumento por medio del cual la Corona daba curso, entre otras, a todas aquellas cuestiones relativas a su política misionera, al gobierno de la Universidad de Coímbra, a la protección de determinadas instituciones de asistencia y, desde 1551, a la administración de las órdenes militares de Cristo, Santiago y Avís, cuyos destinos, tal como ocurriera en Castilla y Aragón, quedaron sujetos desde entonces a la autoridad regia ${ }^{7}$.

No obstante la reformulación de que fueron objeto las relaciones de la Corona con el papado durante el siglo $\mathrm{XVI}^{8}$, la creciente influencia e injerencia de aquélla en los asuntos que tocaban a lo religioso y lo eclesiástico, y su decidido papel, desde la segunda mitad de la centuria de 1500 , en la definición de una política confesional alineada con los presupuestos ideológicos del catolicismo tridentino, conviene no menospreciar, sin embargo, la posición que las estructuras eclesiásticas mantuvieron dentro del campo político portugués. En este sentido, más allá de la creciente influencia y capacidad de intervención de los tribunales inquisitoriales, sujetos en última instancia a la autoridad regia por medio de la inserción del Conselbo Geral do Santo Ofício en el sistema polisinodal de gobierno de la mo-

\footnotetext{
6 PAIVA, José Pedro: «Dioceses e organização eclesiástica», en AzEvedo, Carlos Moreira dir., História Religiosa de Portugal, vol. II, op. cit., sobre todo, pp. 187-194. Durante el reinado de Felipe II, hubo una propuesta, que no tuvo éxito y que partió de D. Jorge de Ataíde, capelão-mor y miembro del Consejo de Portugal, de creación de una nueva diócesis en la ciudad de Santarem; Jorge de Ataíde, Consulta a Felipe II (6 de mayo de 1593), Biblioteca Nacional de Lisboa (=BNL), Pombalina 641 , fol. 635.

7 La bibliografía sobre la "Mesa da Consciência e Ordens» continúa siendo escasa. Véanse apenas, CRUZ, Maria do Rosário S. Themudo Barata de Azevedo, "A Mesa da Consciência e Ordens, o Padroado e as perspectivas da missionação", en Congresso Internacional de História. Missionaçāo portuguesa e encontro de culturas. Actas, op. cit., vol. III, pp. 627-647; DE WITTE, Charles Martial: «Le 'regimento' de la 'Mesa da Consciência' du 24 novembre 1558", Revista Portuguesa de História, 9 (1960), pp. 277-284.

8 Para esta cuestión, la escasa bibliografía existente continúa siendo deudora en buena medida de la obra del Visconde de SANTARÉM: Quadro elementar das relaçoes políticas e diplomáticas de Portugal com as diversas potencias do mundo, desde o princípio da monarchia portugueza até aos nossos dias, vol. 10, Lisboa-París, Typ. da Academia Real das Sciencias-J.P. Aillaud, 1842, así como de los repertorios de fuentes diplomáticas portuguesas. Algunos aspectos sobre las líneas de fuerza que marcaron las relaciones de la Corona portuguesa y el papado a lo largo del siglo XVI, en PAIVA, José Pedro: «A Igreja e o poder», op. cit., passim.
} 
narquía portuguesa, cabe llamar la atención sobre un fenómeno —esencial, por lo demás, en la propia configuración de la confesionalización católica en Portugalcomo es la recepción de que fue objeto la legislación emanada del concilio de Trento. Si bien es verdad que la adopción de sus decretos como leyes del reino, en 1564, no distaba de lo que sucedió en los territorios de la monarquía de Felipe II, en el caso portugués, dicha recepción se produjo sin que obstase cualquier reserva al texto conciliar, ni siquiera en aquellas partes del mismo que cercenaban o podían disminuir la autoridad y jurisdicción regias?.

En principio, la explicación de una medida de esta naturaleza cabría buscarla en el papel desempeñado por el cardenal D. Enrique, entonces regente, dentro del contexto político y religioso del Portugal de la segunda mitad del siglo $\mathrm{XVI}^{10}$. Con todo, una parte de la legislación elaborada a raíz de la publicación del concilio data, en realidad, del reinado efectivo de Sebastián I. Si la ausencia de injerencias por parte de la Corona en sínodos y concilios provinciales portugueses, celebrados a fin de adoptar los decretos tridentinos en el ámbito diocesano, marca asimismo una diferencia sustancial en el proceso de recepción de los mismos con respecto a lo sucedido en los dominios de Felipe II, las disposiciones regias publicadas en tiempo de Sebastián I aumentan tales diferencias, ya que, por medio de las mismas, se reconocieron toda una serie de prerrogativas a la justicia episcopal, que repercutían directamente sobre la jurisdicción regia. Ya algunos de los decretos publicados bajo la regencia del cardenal D. Enrique otorgaban poderes bastante amplios a los diocesanos portugueses en la persecución de pecados públicos y delitos comprendidos entre las materias consideradas mixti foro. Con todo, el alvará publicado en 1569 por el rey D. Sebastián supuso una verdadera disminución de la jurisdicción regia frente a la eclesiástica, cuyos límites, dentro del reino, pasaron a estar definidos por el propio derecho canónico y por los decretos tridentinos. Sólo lós numerosos conflictos que surgirían entre los representantes de ambas instancias llevaron a

9 Para esta cuestión, sigue siendo obligada la consulta de CAETANo, Marcelo: «A recepção e execução dos decretos do Concílio de Trento em Portugal», Revista da Faculdade de Direito da Universidade de Lisboa, 19 (1965), pp. 7-87. En relación con el mismo proceso, dentro de los territorios peninsulares de la monarquía de Felipe II, véase, TelleCHEA, José Ignacio: «Filippo II e il Concilio di Trento", en JeDIN, Hubert ed., Il Concilio di Trento come crocevia della politica europea, Bolonia, Il Mulino, 1979, pp. 109-135; y, sobre todo, el excelente análisis de FerNándeZ TERRICABRAS, Ignasi: Felipe II y el clero secular. La aplicación del concilio de Trento, Madrid, Sociedad Estatal para la Conmemoración de los Centenarios de Felipe II y Carlos V, 2000.

${ }_{10}$ La figura del cardenal D. Enrique no ha sido hasta la fecha suficientemente estudiada, a pesar de constituir una presencia clave del Portugal de mediados del siglo XVI, gracias a la posición privilegiada que, dentro del contexto político y religioso de reino, le suministraron los diferentes cargos que ocupó (arzobispo de Braga y, posteriormente, de Évora y Lisboa, inquisidor general, legado papal, regente y monarca). Sobre el mismo, cabe referir: BETHENCOURT, Francisco: voz "Henri, cardinal du Portugal», in AUBerT, R dir., Dictionnaire d'Histoire et de Géographie écclesiastiques, vol. XXIII, París, Letouzey et Ané, 1990, cols.1207-1213; SILVA, Maria Amélia Polónia da: O Cardeal Infante D. Henrique, Arcebispo de Évora. Um prelado no limiar da viragem tridentina, (Tesis de «Mestrado»), Oporto, Universidade do Porto, 1989.

Hispania, LXIV/1, núm. 216 (2004) 63-94 
reconsiderar la situación y a elaborar la llamada Concordia de 1578, en la que, reconociendo amplios poderes jurisdiccionales a los ordinarios, ésos, con todo, se vieron limitados y, sobre todo, susceptibles de ser recurridos ante la justicia regia, que surgía así como garantía frente a eventuales abusos de la autoridad episcopal ${ }^{11}$.

Es indudable, en todo caso, que los obispos portugueses, por medio de los tribunales diocesanos, de una renovada estructura burocrática, sobre la que tendremos oportunidad de volver, y mediante el recurso a instrumentos eficaces de control del territorio gozaron de una capacidad considerable de intervención sobre las poblaciones primomodernas, sometidas a la acción regular de los diocesanos y de sus oficiales ${ }^{12}$. En realidad, más allá de las sustanciosas rentas que la Iglesia portuguesa poseía, es esa presencia del poder episcopal sobre el territorio (por medio de visitadores, pero también mediante la existencia de vicarios foráneos, arciprestes y, en último término, párrocos), así como la autonomía jurisdiccional de la que gozaba, reforzada por amplias atribuciones en lo que al ejercicio de la justicia se refiere, situaban a los ordinarios lusos en una posición inmejorable dentro del propio campo político, a pesar del creciente control que sobre los mismos vino a ejercer el poder regio.

Esta situación privilegiada - sobre todo, cuando la comparamos con la de los obispos castellanos- permite entender mejor los recelos que encontró Felipe II para ver reconocida su candidatura entre los prelados portugueses y la singularidad que, en el marco de las negociaciones con los diferentes grupos representados en Cortes, asumió aquella que los representantes del monarca mantuvieron con el brazo eclesiástico. Lo cierto es que, salvo casos manifiestamente favorables, como los de D. André de Noronha, D. Jerónimo Osório, D. Pedro de Castilho y D. Jorge de Ataíde (o, por el contrario, empeñados en la causa antoniana, como fue el caso de D. João de Portugal, obispo de Guarda), la jerarquía diocesana mantuvo, en general, una actitud expectante y poco entusiasta ante el advenimiento del rey castellano al trono portugués ${ }^{13}$. A ello se unía, además, el protagonismo que, en el curso de la crisis sucesoria, asumió el clero contrario a la candidatura filipina, que no dudó en recurrir a púlpitos y confesionarios para atizar la oposición a Felipe $\mathrm{II}^{14}$. El monarca, como ya hemos señalado y en su día expuso Fernando Bouza, adoptó en Tomar una estrategia en relación con los representantes del brazo eclesiástico orientada, por un lado,

\footnotetext{
11 Caetano, Marcelo: "A recepção...", passim; Carvalho, Joaquim Ramos: «A jurisdição episcopal sobre leigos em matéria de pecados públicos: As visitas pastorais e o comportamento moral das populações portuguesas de Antigo Regime», Revista Portuguesa de História, 24 (1988), pp. 121-163. El texto de la Concordia de 1578 se encuentra en: CASTRO, Gabriel Pereira de: Monomachia sobre as concordias que fizeram os Reys com os Prelados de Portugal nas duvidas da jurisdiçam ecclesiastica e temporal, Lisboa, José Francisco Mendes, 1738, pp. 228-256.

12 Sobre estas cuestiones, además del trabajo citado de Joaquim Ramos CarvalHo, véase la bibliografia referida en las notas 54 a 56.

13 BoUZA, Fernando: Portugal en la Monarquía Hispánica, vol. II, pp. 580-581.

14 Sobre la cuestión del uso de los púlpitos en la crisis sucesoria, véase, sobre todo, MARQUES, João Francisco: A parenética portuguesa e a dominaşão filipina, Oporto, INIC, 1988, pp. 29-61.
} 
a garantizar los privilegios hasta entonces adquiridos por la Iglesia portuguesa y recogidos, en buena medida, en la mencionada Concordia de 1578; por otro, a respetar el principio de indigenato en la colación de los beneficios del reino; finalmente, a mantener las instituciones eclesiásticas a salvo de contribuciones extraordinarias ${ }^{15}$. En resumen, Felipe II no dudó en sancionar el régimen hasta entonces existente en las relaciones entre el poder regio y el eclesiástico, a pesar del mismo ser menos favorable a la autoridad del monarca que el existente en Castilla, obteniendo así el apoyo de un grupo -el episcopado portugués-, cuyas bases de poder lo convertían en un instrumento esencial para legitimar y consolidar el nuevo reinado.

\section{LA SUPRESIÓN DE LA OPOSICIÓN POLÍTICA}

Consciente del peso que tenían las diferentes instituciones eclesiásticas, así como de la presencia notable de clérigos y religiosos en el campo antoniano, Felipe II, al abandonar el reino que acababa de incorporar a su Corona, optó por una fórmula que, en realidad, iba más allá del llamado "virreinato de sangre», cuya importancia como instrumento de incorporación de Portugal a la Monarquía Hispánica ha sido recientemente señalada ${ }^{16}$. Al hacer recaer en su sobrino la carga virreinal, el rey no sólo escogía como representante de su persona a un miembro de su dinastía, sino que, además, se decidía por la figura de un eclesiástico que, con el favor del pontífice, habría de ser investido como legado ad latere y, años después, también como inquisidor general, colocando así al cardenal Alberto en la cúspide del poder político y religioso portugués. En la carta que en 1581 enviara a Gregorio XIII, Felipe II exponía de forma expresiva las razones que lo llevaban a solicitar la designación de su sobrino para la legacía del reino:

\footnotetext{
«Haviendo mirado mucho lo que importa acertar a tener buena orden y concierto en lo Ecclesiastico deste Reyno, assi por lo q'ello es en si como por lo quedepende desso una gran parte del sosiego y quietud del en lo seglar, movido del exemplo pasado de aver sido tantos años Legado el Ser.mo Rey Don Enrique mi Tio, antes que viniesse a heredar, y el bien que de serlo se seguio, y vista la necessidad presente que tan grande la tiene de remedio, he hallado conveniente mucho ponerle por el mismo camino» ${ }^{17}$.
}

15 Patente das Merces, Graças, e Privilegios, de que ElRei Dom Phelippe nosso senhor fez merce a este seus Regnos, Lisboa, António Ribeiro, 1583 (BNL, Res. 64A, fols. 86-105)

16 BOUZA, Fernando: «A "saudade" dos reinos e a "semelhança do rei". Os vice-reinados de príncipes no Portugal dos Filipes", en id., Portugal no tempo dos Filipes. Política, Cultura, Representações (1580-1668), Lisboa, Cosmos, 2000, pp. 113-126 (antes publicado en Ruggiero Romano, org., Governare il mondo. L'impero spagnolo dal XV al XIX secolo, Palermo, Società Siciliana per. la Storia Patria, 1991, pp. 125-139).

17 Felipe II, Carta al papa Gregorio XIII (Almada, 26.6.1581), Archivo General de Simancas (AGS), Estado-Roma, leg. 939, fol. 145. Citada en CAEIRo, Alberto: $O$ arquiduque Alberto de Aus- 
Ciertamente, en la intención de Felipe II, la elección del cardenal Alberto como legado ad latere obedecía a una necesaria estrategia de supresión de la oposición a su candidatura proveniente de algunos sectores religiosos; tarea en la que, por lo demás, el papado, después de una aparente ambigüedad inicial, motivada por su deseo de intervenir directamente en la cuestión sucesoria, acabó apoyando al monarca castellano por medio, como se verá a continuación, de la sucesiva promulgación de breves y monitorias que conminaban a la persecución y juicio de los eclesiásticos y religiosos seguidores de D. Antonio. En todo caso, los objetivos que el monarca perseguía por medio de esta acumulación de poderes en la persona del cardenal Alberto iban más allá de esta finalidad inmediata, reconociendo expresamente el papel que desempeñaban las instancias eclesiásticas y religiosas a la hora de lograr «el sosiego y quietud del Reino», y poniendo de manifiesto, por consiguiente, la necesidad de, en alguna medida, tutelarlas para poder consolidar su señorío sobre Portugal.

En realidad, la situación en 1583 era especialmente delicada y requería, por tanto, de fórmulas que, no sólo supliesen adecuadamente la ausencia del monarca en un reino que, hasta entonces, siempre había contado con la presencia de su rey natural, sino que permitiesen asimismo ejercer la autoridad sobre una poderosa jerarquía eclesiástica y religiosa, heredada y no siempre afecta o entusiasta de la nueva dinastía (si bien es cierto que, en este punto, las posturas de los distintos grupos e individuos estuvieron lejos de ser uniformes). Así, por medio de la persona del cardenal Alberto, Felipe II recurría a un modelo que ya había sido ensayado en el período - también delicado desde el punto de vista político- de la minoría de Sebastián I, cuando el cardenal D. Enrique unió a sus funciones de legado e inquisidor general las de regente, hasta que, en 1568, su sobrino asumió el gobierno directo del reino ${ }^{18}$.

Los amplios poderes que, tal como lo había solicitado el monarca en 1581, Gregorio XIII atribuyó al cardenal Alberto como legado ad latere en Portugal, contemplaban, entre otros aspectos, la posibilidad de visitar iglesias, monasterios y, en general, lugares píos, incluidos aquéllos exentos; la facultad para actuar la reforma de congregaciones religiosas; el castigo a "desobedientes», falsarios y toda suerte de delincuentes, sin que al respecto obstase exención de foro alguna; la capacidad para tomar conocimiento, sin perjuicio de la autoridad episcopal, de cualquier causa que anduviese en los tribunales ordinarios eclesiásticos ${ }^{19}$. Pertrechado, por tanto, de una extensa capacidad jurisdiccional que, de hecho, le permitía un amplio margen de actuación sobre las instancias

tria. Vice-rei e inquisidor-mor de Portugal, cardeal legado do Papa, governador e depois soberano dos Países Baixos. História e Arte, Lisboa, ed. do autor, 1961, pp. 292-293.

18 Para este período, véase CRUZ, Maria do Rosário S. Themudo Barata: As regências na minoridade de D. Sebastiāo. Elementos para uma bistória estrutural, 2 vols., Lisboa, Imprensa Nacional-Casa da Moeda, 1992.

19. Gregorio XIII, Breve de 9 de febrero de 1583, AGS, Estado-Roma, leg. 1855, fol. 169. Reproducido en CAEIRO, Alberto, $O$ arquiduque., págs. 532-539.

Hispania, LXIV/1, núm. 216 (2004) 63-94 
eclesiásticas, tanto regulares como seculares, la legacía pontificia sirvió al cardenal Alberto para desarrollar unos de los ejes fundamentales de la política de Felipe II en los primeros años de su reinado portugués, como era la de acallar la contestación que, por parte de algunos grupos e individualidades provenientes del campo religioso, ponía en causa su legitimidad como monarca, sosteniendo el partido de D. Antonio, Prior de Crato.

En este sentido, la acción del cardenal Alberto a lo largo de su gobierno se hizo sentir con alguna intensidad en el ámbito de las órdenes religiosas, donde la oposición a la candidatura filipina parecía haber tenido cierta incidencia. En realidad, el control sobre las jerarquías de los institutos religiosos fue un objetivo esencial desde los primeros momentos de la crisis sucesoria, cuando se hizo necesario frenar los efectos negativos que estaban teniendo las acciones de los regulares y que, en ocasiones, podían envolver a enteras comunidades de religiosos. Son conocidas, de hecho, las indicaciones que el monarca castellano envió, ya en 1579, a su embajador en Roma para que lograse del general de la Compañía de Jesús, Everardo Mercuriano, la prohibición de que sus súbditos portugueses se inmiscuyesen en las cuestiones que tocaban a la sucesión del reino ${ }^{20}$. Asimismo, durante la crisis de 1580-81, la elección de un nuevo provincial dominico, tras la muerte de Fr. António de Sousa, se vio condicionada por la intervención del cardenal Riario, el cual, en calidad de legado pontificio y, ciertamente, alentado por Felipe II, impuso provisionalmente a Fr. Luis de Granada como superior de la orden en Portugal, evitando que dicha función pudiese recaer en quien era contrario al monarca castellano y situando en la misma a quien no dudó en iniciar de inmediato las acciones canónicas necesarias contra los religiosos de la orden que, abiertamente, se habían colocado del lado antoniano ${ }^{21}$.

En el caso de los Canónigos Regulares de San Agustín, también conocidos como crúzios por ser el monasterio de Santa Cruz de Coímbra el más emblemático de esta congregación en Portugal, la deposición del vicario general de la provincia, D. Lourenço Leite, directamente involucrado en las acciones de D. Antonio, pasó por la movilización de dos de los visitadores de la orden, pertenecientes al monasterio de São Vicente de Fora en Lisboa y partidarios de la candidatura filipina. La deposición fue ratificada por el propio representante pontificio, que nombró al prior de São Vicente, D. Pedro da Assunção, como vicario general y visitador de la congregación, permitiendo así la sustitución de los superiores de los diferentes monasterios de la orden y la convocatoria de un capítulo general,

\footnotetext{
20 Una copia de la carta enviada por Felipe II a su embajador, Juan de Zúñiga, en BRANDÃo, Mário: Alguns documentos relativos a 1580, Coímbra, Coimbra Editora, 1943, pp. 24-26. Véase, además, RoDrigues, Francisco: História da Companbia de Jesus na assitência de Portugal, vol. II (2), Oporto, Apostolado da Imprensa, 1938, pp. 400-409.

${ }^{21}$ A propósito de las acciones canónicas contra los dominicos partidarios de $\mathrm{D}$. António, véase la patente de Fr. Luis de Granada, de 28 de enero de 1581, publicada en Colección de Documentos Inéditos para la Historia de España (CODOIN), t. XXXV, pp. 177-181.
} 
celebrado en 1581 , en el que aquél fue reelegido como provincial ${ }^{22}$. A pesar de tales diligencias, la congregación agustina no fue, ciertamente, una de las más sosegadas durante la crisis sucesoria y la necesidad de controlar el acceso al gobierno de la orden, impidiendo la presencia de simpatizantes de la causa antoniana, se haría sentir aún en 1584 y 1590 . La injerencia de Felipe II en los capítulos de la congregación se hizo explícita en sendas ocasiones a través de la acción de su sobrino, que, con ocasión del capítulo celebrado en marzo de 1584, escribió a los padres capitulares advirtiéndoles de que no admitiesen a la elección de vicario general a quienes habían sido inculpados por apoyar a D. António y reservándose la confirmación de la persona que el capítulo eligiese para ejercer dicha función ${ }^{23}$. En 1590, era D. Jorge de Ataíde quien, en su calidad de miembro del Consejo de Portugal, advertía en una consulta al monarca de la necesidad de poner sobre aviso al archiduque Alberto de la inminente celebración del capítulo crúzio, con el fin de que impidiese nuevamente la participación de antiguos antonianos en la elección del provincial, porque, como afirmaba, «está esta religião quieta e temo, se estes bomens uotarem, que elejão algum que, posto que não aja sido dos parciaes de D. Ant ${ }^{\circ}$., seja froxo na goarda da obseruancia da ordem, que be o que estes religiosos amigos de D. Ant ${ }^{\circ}$. pretendem mais que outra cousa» ${ }^{24}$.

Como se ve, una década después de la incorporación de la Corona portuguesa a la Monarquía de Felipe II, los ánimos se encontraban lejos de estar aquietados en el seno de algunas de las congregaciones religiosas que se habían visto más afectadas por los acontecimientos de la crisis sucesoria y que, tras el desembarco de D. António en las costas portuguesas, en 1589, continuaban despertando algunos recelos en el poder filipino ${ }^{25}$. Este tipo de interferencias del poder regio sobre los mecanismos de gobierno de determinadas órdenes religiosas afectó, por lo demás, a otras congregaciones, como los carmelitas calzados $^{26}$, los jerónimos ${ }^{27}$ o los benedictinos ${ }^{28}$, y, a pesar de la particular co-

22 CRUZ, Marcos da: Crónica do Mosteiro de São Vicente, Biblioteca Geral da Universidade de Coimbra, ms. 632, fols. 108v-115. Texto parcialmente publicado en BRANDÃO, Mário: Coimbra e D. António Rei de Portugal, vol. III: Documentos de 1582 a 1598, Coímbra, Publicações do Arquivo e Museu da Universidade de Coimbra, 1947, pp. 155-167.

23 El traslado de la carta del archiduque Alberto, fechada el 16 de marzo de 1584, ibidem, p. 166.

24 Jorge de Ataíde, Consulta a Felipe II (8 de abril de 1590), BNL, Pombalina 641, fol. 591.

${ }_{25}$ En 1589, por ejemplo, las sospechas de que los carmelitas calzados del convento de Lisboa almacenasen armas para apoyar a los antonianos, llevó al archiduque Alberto a nombrar a Jerónimo Gracián, a pesar de ser miembro de la rama descalza, como visitador de la orden. La actuación del virrey, de hecho, llevó al envío inmediato desde curia carmelita en Roma de un visitador apostólico, Fr. Miguel Carranza, con el objeto de sustituir a Gracián; BAYÓN, Balbino Velasco: História da Ordem do Carmo em Portugal, Lisboa, Ed. Paulinas, 2001, pp. 120-124.

26. Ya en 1588, el cardenal Alberto hizo valer sus poderes de legado para impedir la presencia de Fr..Pedro Brandão en el capítulo provincial de la orden, si bien la intervención del sobrino de Felipe II sobre las estructuras de gobierno de la congregación carmelita se hizo más incisiva con ocasión del capítulo celebrado en 1591, tras la visita realizada por Gracián y, posteriormente, por Carranza. En dicha ocasión, el cardenal envió una patente en la que ordenaba que no se eligiese otro 
yuntura política, no distaban formalmente de los procedimientos empleados en el pasado por los monarcas portugueses, dentro de lo que fue una política de reforma de los institutos regulares que corrió paralela a la habida en otros territorios de la Península y que, de hecho, tuvo similares raíces espirituales y no pocas influencias recíprocas ${ }^{29}$. Lo cierto es que las injerencias de Felipe II, por medio del cardenal Alberto, en la vida interna de algunas congregaciones religiosas, además de obedecer a una necesidad de aislar a los grupos antonianos, no se pueden disociar tampoco de una voluntad de encerrar los procesos de reforma iniciados por sus predecesores y de llegar, en algunos casos, a fórmulas que permitiesen un mayor control, por parte de la Corona, de las estructuras de gobierno de determinadas congregaciones, tal como había sucedido en Castilla. Es aquí, de hecho, donde cabría inserir algunos proyectos de «unión de órdenes», que apenas se materizaliarían, sin embargo, en el caso de los religiosos jerónimos, cuyos conventos fueron incorporados a la congregación castellana en $1595^{30}$.

provincial que no fuese alguno de los cuatro religiosos que él mismo proponía, como, de hecho, sucesió; Cotrim, Jorge: Recuerdos del Carmelo Luçitano, que contienen los capitolos Provinçiales, que se celebraron en la dicha Provinçia desde su stabilidad, hasta el precente año de 1675 (ed. Balbino Velasco Bayón y Manuel Gomes Quintãos), Carmelo Lusitano, 14 (1996), pp. 155 y 156-157. Véase, igualmente, BAYÓN, Balbino Velasco: História da Ordem do Carmo em Portugal, p. 124.

27 SANTOS, Cândido dos: Os Jerónimos em Portugal. Das origens aos finais do século XVI, Oporto, INIC, 1980, p. 32.

28 La intervención sobre la congregación benedictina portuguesa se materializó mediante el nombramiento, en 1588, de dos visitadores provenientes de la congregación de Valladolid, Fr. Álvaro de Salazar y Fr. Sebastián de Villoslada, que se encargaron de cerrar el proceso de reforma de los benedictinos, inciado ya en tiempos de Juan III y concluido con la unión jurídica a la congregación benedictina portuguesa de varios monasterios y con la elaboración y aprobación de constituciones, en 1590 . A este respecto, véase, ZARAGOZA PASCUAL, Ernesto: «La congregación benedictina observante de Valladolid y la reforma de los monasterios benedictinos portugueses (1390-1590)", en Os Beneditinos na Europa: $1^{\circ}$ Congresso internacional, 23 a 26 de Novembro de 1995. Santo Tirso, Santo Tirso, Câmara Municipal, 1998, pp. 237-246. En todo caso, la preocupación del poder regio por la presencia de antonianos dentro de la congregación benedictina se hace patente en las referencias al respecto que surgen en el memorial «secreto» que Fr. Álvaro de Salazar envió al cardenal Alberto tras la realización de la visita; memorial publicado por ZARAGOZA PASCUAL, Ernesto: «Reforma de los benedictinos portugueses (1588-1589)", Theologica, $2^{\text {a }}$ série, 17 (1982), pp. 143-218.

29 En relación con las reformas de las diferentes familias y congregaciones portuguesas a lo largo del siglo XVI, sigue siendo imprescindible el trabajo de DiAs, José Sebastião da Silva: Correntes de sentimento religioso em Portugal (Sécs. XVI a XVIII), t. I(1), Coímbra, Universidade, 1960; pp. 93-177. Sobre las elementos de unión entre los procesos de reforma desarrollados en Portugal y en los otros territorios de la Península, además de este trabajo, son igualmente esenciales el ensayo clásico de ASENSIO, Eugenio: «El erasmismo y las corrientes espirituales afines. Conversos, franciscanos, italianizantes», Revista de Filología Española, 36 (1952), pp. 31-99, y, más recientes, los estudios de CaRVALHO, José Adriano de Freitas: Gertrudes de Helfa e Espanha, Oporto, INIC, 1986; id., Nobres leteras... Fermosos volumes... Inventários das bibliotecas dos franciscanos observantes em Portugal no século XV. Os traços de uniäo das reformas peninsulares, Oporto, Faculdade de Letras, 1995.

30 SANTOS, Cândido dos: Os Jerónimos em Portugal, pp. 32-37.

Hispania, LXIV/1, núm. 216 (2004) 63-94 
En definitiva, el control sobre los instrumentos de gobierno de los institutos regulares, piezas fundamentales, por lo demás, en la actividad de disciplinamiento social desarrollada por los grupos religiosos de la época ${ }^{31}$ y en la propia política de expansión y evangelización de los territorios asiáticos y americanos bajo dominio de la Corona portuguesa, constituyó una estrategia fundamental del poder filipino, que se hizo sentir de forma más acentuada durante el virreinato del cardenal Alberto, en su calidad de legado pontificio. Con todo, el control de los resortes del poder eclesiástico, más allá de las acciones que se llevaron a cabo sobre los institutos regulares, fue, sin duda, uno de los principales objetivos que, desde un primer momento, persiguió tanto el partido antoniano como el propio Felipe II. Es bien conocido que D. António supo rodearse de un grupo relativamente importante de clérigos, entre los cuales, además del obispo de Guarda, D. João de Portugal, se encontraban personajes como Lourenço Leite y Afonso Henriques, prior y canónigo, respectivamente, del monasterio Santa Cruz de Coímbra; Simão Mascarenhas, deán de la catedral de Évora; Fr. Heitor Pinto (OSH) y Gaspar Dias Estaço, canónigos de Coímbra y Évora; o Fr. Luís de Sotomayor (OP), profesor de Teología en la universidad conimbricense. Junto al auxilio de este grupo, cuyos miembros, por su estatuto y su cercanía al pretendiente portugués, quedaron excluidos del perdón de 1581, las acciones de D. António, tras su proclamación en Santarém, dejan percibir los intentos por controlar las instancias eclesiásticas seculares allí donde fue estableciendo sus bases de poder y de resistencia a los ejércitos de Felipe II. Así, mientras el arzobispo D. Jorge de Almeida, a la sazón uno de los gobernadores del reino, hubo de refugiarse en la villa de Alhandra tras la entrada del Prior en Lisboa, el obispo-chantre, D. Manuel de Almada, no dudó en ocupar el lugar del prelado con un gesto tan significativo como el de recibir en la catedral y bajo palio a $\mathrm{D}$. António, sumándose de este modo a las ceremonias de aclamación que tuvieron lugar a la llegada del mismo a la ciudad ${ }^{32}$. Junto a este tipo de hechos, otros elementos dejan un margen de duda aún menor en cuanto a las pretensiones del Prior de Crato por «instituir» una Iglesia que le fuese adepta. En este sentido, cabe señalar determinados gestos de carácter político-institucional, como el nombramiento de Afonso Henriques como capelão-mor o el uso de los derechos que el Padroado otorgaba al monarca portugués, materializado en la colación de beneficios de varias iglesias del reino ${ }^{33}$.

31 Sobre este particular nos permitimos remitir a PALOMO, Federico: Fazer dos campos escolas excelentes. Os jesuitas de Évora e as missöes do interior em Portugal (1551-1630), Lisboa, FCG-FCT, 2003.

32 Un breve relato de dichas ceremonias, en el que se hace mención al recibimiento de D. Antonio en la catedral de Lisboa por D. Manuel de Almada, en SOARES, Pero Roiz: Memorial (ed. de M. Lopes de ALMEIDA), Coímbra, Universidade, 1953, pp. 166-167.

33 Véanse, en este sentido, algunas de las cartas de presentación de D. António, dirigidas a diversos obispos portugueses, que se conservan en el fondo de las Chacelarias de $\mathrm{D}$. Sebastião e $\mathrm{D}$. Henrique de la Torre do Tombo (Lisboa) y que publicó SERRÃo, Joaquim Veríssimo: $O$ reinado de $D$.

Hispania, LXIV/1, núm. 216 (2004) 63-94 
Con todo, más expresivos de las intenciones de $\mathrm{D}$. António a este respecto fueron los sucesos de la isla Tercera, cuando, en 1581, el Prior se dirigió al cabildo de Angra, conminándolo a que, ante la ausencia del obispo D. Pedro de Castilho (retirado a la isla de São Miguel por sus desavenencias con el corregidor Ciprião de Figueiredo), eligiese un nuevo vicario general del obispado, e instándolo, además, a que no obedeciese al prelado. A diferencia de lo que ocurrió en la isla de Madeira, cuyo cabildo catedralicio se negó a acatar una carta escrita en términos similares, los canónigos de Angra, de hecho, eligieron al tesorero de la catedral como nuevo vicario general, que pasó así a gobernar el obispado durante el período en el que las fuerzas de $\mathrm{D}$. António controlaron la mencionada isla del archipiélago de Azores ${ }^{34}$.

A pesar de la aparente fragilidad del poder filipino ante la acción desarrollada por predicadores y confesores - probablemente, la forma más efectiva de respuesta a la candidatura castellana, por su capacidad movilizadora de la opinión y por recurrir a argumentos de índole religiosa que buscaban debilitar la legitimidad de Felipe II - , no cabe duda de que la capacidad del monarca para, en los momentos iniciales de la crisis, controlar los instrumentos del poder eclesiástico acabó siendo bastante eficaz, gracias a su afirmación militar y a su disposición para la negociación, como también, en parte, debido al apoyo que finalmente obtendría de Gregorio XIII. Si en un principio la presencia del nuncio Frumento en la proclamación de D. António en Santarém parecía confirmar las supuestas simpatías del representante pontificio por el partido del prior, y si las diligencias dilatorias de Felipe II, en 1580, para evitar la entrada en el reino del cardenal Riario, como nuevo legado ad latere, respondían a la necesidad de impedir cualquier tipo de injerencia papal en la solución de problema sucesorio portugués, la rápida afirmación militar y negociadora de Felipe II, la propia proclamación de su realeza en Castro Marim, por una parte de los gobernadores del reino, así como la debilidad del partido antoniano y algunos de sus excesos, condujeron no sólo a la salida de Frumento de Portugal, como a la adopción, por parte de Riario (y con él, del pontífice), de una postura de abierto sostén al monarca castellano. Es entonces cuando el nuevo legado comienza a ordenar a los prelados diocesanos que instauren procesos canónicos contra todos los clérigos involucrados en los hechos de guerra que estaban teniendo lugar ${ }^{35}$, añadiendo posteriormente, a 11 de febrero de 1581 , un edicto por el que se condenaba con la excomunión a aquellos predicadores y confesores que, en el uso de sus ministerios, tratasen las cuestiones que tocaban a la

\footnotetext{
António, Prior do Crato, Coímbra, Instituto de Alta Cultura, 1956, pp. 548-549, 551-552, 565-566 y $571-574$.

34 Se da noticia de este episodio, incluido en un memorial conservado en el Archivio Segreto Vaticano, en CASTRO, José de: $O$ Prior do Crato, Lisboa, União Gráfica, 1942, pp. 287-289.

35 Ibidem, pp. 253-254.
}

Hispania, LXIV/1, núm. 216 (2004) 63-94 
sucesión del reino ${ }^{36}$, y una carta monitoria en la que ordenaba a todos los clérigos regulares y seculares que había tomado armas en favor de D. António que se presentasen en el plazo de nueve días ante el propio legado, para descargo de las culpas en las que habían incurrido ${ }^{37}$.

A partir de entonces y durante los años que siguieron, se asiste a la promulgación de toda una serie de decretos pontificios, por medio de los cuales se favorecía la persecución y castigo de clérigos y religiosos que de forma manifiesta habían sostenido y sostenían el partido antoniano. Si, por medio de un breve, expedido a 18 de marzo de 1582, el papa encomendaba a $\mathrm{D}$. André de Noronha, obispo de Leiría y sujeto de la confianza de Felipe II, el juicio de D. João de Portugal, obispo de Guarda ${ }^{38}$, las concesiones de Gregorio XIII a la estrategia del nuevo monarca portugués habrían de adquirir contornos bastante más significativos cuando, a 15 de octubre del año siguiente, un nuevo breve convidaba a los prelados diocesanos portugueses a que, sin que obstase cualquier tipo de inmunidad de foro, entregasen a la justicia secular a los eclesiásticos -seculares y regulares - contrarios al partido filipino; breve que se vio completado, días después, por un nuevo reescrito en el que se delegaba en el cardenal Alberto el juicio de dichos sujetos ${ }^{39}$. En realidad, si el primero de estos diplomas suponía, aparentemente, un consentimiento a la intromisión de la justicia regia en causas que, por el estatuto de aforados de sus protagonistas, apenas podían ser juzgadas por tribunales eclesiásticos, lo cierto es que el breve, con todo, dejaba esta posibilidad al criterio de los obispos portugueses, que, en este sentido, podían conservar, si así lo entendían, dichas causas bajo su jurisdicción. No así el reescrito que Felipe II alcanzó el 4 de noviembre, por medio del cual, si bien el juicio de los referidos miembros del clero portugués se mantenía en al ámbito de la jurisdicción eclesiástica, ésta debía ser ejecutada, en dichas causas, apenas por el cardenal Alberto, en su condición de legado pontificio.

La aplicación de esta última disposición de Gregorio XIII, de hecho, no dejó de suscitar recelos y algún que otro conflicto con los diocesanos portugueses, como el que, en 1584, enfrentó al cardenal con el arzobispo de Évora, D. Teotónio de Braganza, en relación con el proceso del canónigo eborense Gaspar Dias Estaço. La disputa fue parcialmente reconstruida por José de Castro, a partir de la documentación conservada en los archivos vaticanos, y muestra, no sólo el empeño de Felipe II, en función del rescrito de 4 de noviembre de 1583, por apartar a los diocesanos de las causas contra los clérigos antonianos, como las resistencias de algunos prelados frente a lo que entendían ser una intromisión o, al menos, una disminución de su jurisdicción. En efecto, entre los argumentos presentados por D. Teotónio al pontífice, en defensa de su actuación, el arzobis-

\footnotetext{
36 Alejandro Riario, Edicto de 11 de febrero de 1581, Corpo Diplomático Portuguez (ed. de Jaime Constantino de Freitas Moniz), tomo XII, Lisboa, Academia Real das Sciencias, 1902, pp. 1-2.

37 Id., Carta monitoria de 18 de febrero de 1581, ibidem, pp. 2-3.

38 Gregorio XIII, Breve Pro parte, de 18 de marzo de 1582, ibidem, pp. 8-10

39 CAstro, José de: O Prior do Crato, p. 339.
} 
po contestaba la propia legitimidad del mencionado reescrito, toda vez que, en su opinión, éste había sido alcanzado mediante argumentos falsos, que acusaban a los prelados portugueses de incuria en el procesamiento de los clérigos «rebeldes». Bien es verdad que, en este caso, las pretensiones de Felipe II fueron a dar con un personaje que, como se verá, fue particularmente consciente de sus prerrogativas jurisdiccionales y del significado que éstas adquirían como instrumento para el ejercicio de su autoridad como diocesano, dentro de la configuración del poder eclesiástico que el concilio tridentino había establecido y que atribuía a los obispos un papel central en el gobierno de la Iglesia y de sus fieles. Esto explica que $\mathrm{D}$. Teotónio de Braganza avanzase con una causa que el tribunal diocesano de Évora, en realidad, había iniciado en 1582. El prelado hacía así caso omiso, por un lado, del reescrito de noviembre de 1583 , de los edictos publicados posteriormente por el auditor de la legacía y de la carta del monarca en la que se le conminaba a que entregase el proceso al cardenal Alberto; por otro lado, dictaba sentencia condenatoria contra el canónigo; finalmente, contestaba la inhibición sobre la causa lanzada por la legacía, dado que ésa había sido ya encerrada por los jueces del auditorio eclesiástico eborense ${ }^{40}$.

\section{El PODER EPISCOPAL Y LA CONSOLIDACIÓN DE LA REALEZA DE FELIPE II EN PORTUGAL}

A pesar de episodios como éste, no se puede afirmar que las relaciones entre el poder regio filipino y los obispos portugueses, durante el reinado de Felipe II, estuviesen regidas por sentimientos "protonacionalistas» que alimentasen una oposición latente a la nueva dinastía. Bien por el contrario, fueron los elementos de naturaleza corporativa, directamente ligados a la manutención y garantía de conservación de los privilegios del episcopado, los que fundamentaron unas relaciones caracterizadas por un grado importante de concordia y cooperación. Conviene no olvidar, por un lado, que los diocesanos constituyeron el grueso de los representantes con los que Felipe II tuvo que negociar los capítulos relativos al estado eclesiástico, en un Estatuto de Tomar que quedaba aún demasiado próximo en el tiempo para que fuese susceptible de alteraciones o incumplimientos significativos. Por otro, es asimismo necesario subrayar la continuidad, en relación con los reinados anteriores, de una implicación directa de las jerarquías eclesiásticas portuguesas en las propias tareas de gobierno del reino, siendo posible afirmar que la presencia de las mismas en las más altas instancias de la administración del Portugal filipino fue una constante, al menos durante los reinados de los dos primeros representantes de la dinastía de Habsburgo. Si en 1593 y 1603, respectivamente, el arzobispo de Lisboa, D. Miguel de Castro, y el obispo de Coímbra, D. Afonso de Castelo Branco, fue-

40 Ibidem., pp. 340-348.

Hispania, LXIV/1, núm. 216 (2004) 63-94 
ron elegidos como gobernadores del reino, mucho más decisiva resultó, sin duda, la implicación de personajes como D. Jorge de Ataíde, obispo de Viseu y capelão-mor, que pasó a formar parte del recién creado Consejo de Portugal, o como D. Pedro de Castilho, obispo de Angra y, más tarde de Leiría, presidente del más importante tribunal regio lisboeta —el Desembargo do Paço-, que sería nombrado, ya en tiempo de Felipe III, inquisidor general (1605-15) y virrey de Portugal (1605-07 y 1612-13) 1 .

Al mismo tiempo, la renovación progresiva de la jerarquía diocesana portuguesa habría de jugar a favor de Felipe II y sus sucesores, que, siguiendo una política idéntica a la observada en otros territorios de la Monarquía y a la que los propios monarcas portugueses habían empleado a lo largo del siglo XVI, hicieron de sus prerrogativas de presentación un instrumento de control y de generación informal de fidelidades personales dentro del campo religioso portugués, como, de hecho, se haría patente en la crisis de 1640, con las importantes fracturas que se produjeron entre los diferentes grupos eclesiásticos (obispos, Inquisición, órdenes religiosas) ${ }^{42}$. Sin obviar el peso que los criterios de naturaleza religiosa tuvieron en la colación de las sedes episcopales, cuyo estudio, probablemente, ofrecería nuevas pistas en relación con la política confesional observada durante los diferentes reinados filipinos en Portugal, las sucesivas vacantes que, por muerte o renuncia de sus titulares, se fueron creando en el mapa episcopal del reino portugués entre 1580 y 1598, sirvieron para, en algunos casos, "premiar» a quienes se habían mostrado o se mostraban particularmente afectos al poder de Felipe $\mathrm{II}^{43}$. Si la eficaz resistencia a los embates antonianos del prelado de Madeira, D. Jerónimo Barreto, y, sobre todo, de D. António de Castilho, obispo de Angra, durante la crisis de 1580-83, les valió,

41 Sobre la figura de D. Pedro de Castilho, que, al igual que D. Jorge de Ataíde, merecería una monografía que pusiese de manifiesto su papel central en el gobierno filipino de Portugal, véase el ensayo de argaça, Carlos M. VEIGA: «D. Pedro de Castilho. Esboço de uma carreira no governo espanhol de Portugal», en Primeiras Jornadas de História Moderna, vol. I, Lisboa, Centro de História da Universidade de Lisboa, 1986, pp. 356-370. A propósito de D. Jorge de Ataíde cabe remitir a los relatos biográficos de la época, como los que se conservan manuscritos en Biblioteca da Ajuda (=BA), cód. 51-IX-9, fols. 260-265 y 274-281; Biblioteca Nacional de Madrid (=BNM), ms. 11751.

42 Para Portugal, un primer análisis sobre esta cuestión se encuentra en PAIVA, José Pedro: "Os mentores: Bispos", en AzEvedo, Carlos Moreira dir., História Religiosa de Portugal, vol. II, pp. 225-235. Para España y, en concreto, para el período de Felipe II, son fundamentales los estudios de FERNÁNDEZ TERRICABRAS, Ignasi: Felipe II y el clero secular, pp. 211-246; id., «Por una geografía del Patronato Regio: teólogos y juristas en las presentaciones episcopales de Felipe II", en MARTíNEZ Ruiz, Enrique, y SuÁrez Grimón, Vicente eds., Iglesia y Sociedad en el Antiguo Régimen, Las Palmas, Universidad de Las Palmas de Gran Canaria, 1994, pp. 591-599.

43 Las únicas sedes episcopales que, durante todo el reinado portugués de Felipe II, mantuvieron el mismo titular, nombrado antes de la llegada al trono del monarca castellano, fueron Évora (D. Teotónio de Bragança) y Lamego (D. António Teles de Meneses), y, dentro de los territorios asiáticos, Macau (D. Fr. Leonardo de Sá) y Malaca (D. João Ribeiro Gaio); cfr. ALMEIDA, Fortunato de: História da Igreja em Portugal, vol. II, pp. 597-678. 
respectivamente, la promoción a las sedes de Faro (1585) y Leiría (1583), fueron igualmente significativas, desde el punto de vista político, la designación de D. Jorge de Ataíde como capelão-mor, la transferencia del obispo de Portalegre, D. André de Noronha, a la sede castellana de Plasencia (1581), la promoción de otro miembro de esta familia, D. Nuno de Noronha; a los obispados de Viseu (1586) y Guarda (1594) y la elección, en 1582, de D. João Afonso de Meneses, un vehemente defensor de la candidatura filipina, para ocupar el arzobispado de Braga, tras la renuncia al mismo de Fr. Bartolomeu dos Mártires. Identicos criterios, de hecho, debieron animar la elección para la misma sede, en 1587, de un personaje como Fr. Agostinho de Castro, cuya trayectoria como reformador de la orden agustina en Alemania lo había vinculado estrechamente a la emperatriz $\mathrm{D}^{\mathrm{a}}$. María, hermana de Felipe $\mathrm{II}^{44}$.

Junto a este tipo de lazos «políticos», construidos a lo largo del reinado, el respeto por la letra del estatuto de Tomar, garante de los privilegios de que gozaba la Iglesia portuguesa y, por consiguiente, de la autoridad diocesana sobre el territorio y las poblaciones del reino, no dejó de ser, como señalábamos, un factor esencial en la propia articulación de las relaciones entre el poder regio representado por el nuevo monarca y el episcopado portugués, que acabó por convertirse en instrumento de consolidación y legitimación del poder filipino. En este sentido, resulta significativo el hecho de que los conflictos entre los diocesanos y la autoridad regia fuesen puntuales, aumentando apenas con la alteración que la salida del cardenal Alberto del reino produjo en el seno del campo político portugués y en las relaciones de fuerza entre los diferentes polos de poder que lo integraban. Es en ese contexto en el que las luchas de jurisdicción, entendidas como forma de ejercicio de la política altomoderna, se ven favorecidas, debido, entre otros factores, a la ausencia de un monarca, cuya representación no asentaba ya en una persona unida al rey por vínculos de sangre, sino en un número reducido de gobernadores, miembros todos ellos de los grupos privilegiados portugueses ${ }^{45}$.

En efecto, analizados desde esta perspectiva, cobran sentido episodios como el que protagonizó, una vez más, el arzobispo de Évora, D. Teotonio de Bra-

\footnotetext{
44 Sobre la figura de Fr. Agostinho de Castro, que hasta la fecha de su elevación a la dignidad arzobispal fue superior de los agustinos portugueses, véanse apenas las notas incluidas por ALMEIDA, Fortunato de: História da Igreja em Portugal, p. 601.

45 Sobre la alteración que en el campo político portugués supuso la salida del reino del cardenal Alberto, favoreciendo la conflictuosidad entre los grupos de poder, véase: BouZA, Fernando: «Entre as Alterações de Beja (1593) e a "Revolta dos Ingleses" (1596), em Lisboa. Luta política no último Portugal do primeiro Filipe», en id., Portugal no tempo dos Filipes, pp. 125-157 (antes publicado en Studia Historia - Historia Moderna, 17 (1997), pp. 91-120). En relación con la cuestión de las luchas jurisdiccionales como ejercicio de la política en los siglos XVI y XVII, centrado además en el último período de Portugal filipino, es fundamental la consulta de SCHAUB, Jean-Frédéric: Le Portugal au temps du Comte-Duc d'Olivares (1621-1640). Le conflit de jurisdictions comme exercice de la politique, Madrid, Casa de Velázquez, 2001.
}

Hispania, LXIV/1, núm. 216 (2004) 63-94 
ganza, en 1593. Originado en una disputa jurisdiccional sobre una causa testamentaria entre los oficiales del auditorio diocesano eborense y el provedor regio $^{46}$, el conflicto fue adquiriendo dimensiones de mayor gravedad, como consecuencia del propio empeño del arzobispo en la defensa de su autoridad, que le valdría juicios como el que expresaba el gobernador Juan de Silva en una carta al monarca, en la que calificaba a $\mathrm{D}$. Teotónio de no ser «tan prudente que sepa haçer diferençia entre el çelo y la porfia», lo que le llevaba a hacerse «protector de la Jurisdiçion eclesiastica, empeñando en ello la honrra y la conçiençia»" ${ }^{47}$. Lo cierto es que, a las escaramuzas iniciales entre el oficial regio y los representantes diocesanos, siguió la imposición de un entredicho sobre la ciudad de Évora, por parte del prelado; la petición de comparecencia ante el principal tribunal regio, el Desembargo do Paşo, del vicario general del arzobispado y, posteriormente, del propio $\mathrm{D}$. Teotónio ${ }^{48}$; la renovación en sede pontificia de una vieja cuestión, suscitada en varios momentos a lo largo del siglo XVI, en torno a un capítulo de las Ordenações del reino, que sometían al juicio seglar a los clérigos exentos (es decir, a los que carecían de superior dentro de Portugal, como era el caso de los arzobispos) ${ }^{49}$; la publicación, en abril de 1594, de la bula In coena domini, en toda su extensión y acompañada de carta del nuncio Aldobrandini en la que se denunciaban los atropellos de que era objeto la justi-

46 Realizamos un primer análisis de este conflicto en PALOMO, Federico: «La autoridad de los prelados postridentinos y la sociedad moderna. El gobierno de don Teotonio de Braganza en el arzobispado de Évora (1578-1602), Hispania Sacra, 47 (1995), pp. 611-614.

47 Juan de Silva, Carta a Felipe II (Marzo de 1594), BNM, ms. 1439, fol. 248.

$48 \mathrm{El}$ propio Juan de Silva informaba al rey de cómo, ante la petición de comparecencia ante el Desembargo do Paço del vicario general eborense, el arzobispo revocó la jurisdicción de su oficial, asumiéndola él mismo y colocando así al tribunal regio en la tesitura de tener que convocar al propio prelado; ibidem, fols. 248-248v. Sobre esta cuestión y la preocupación que la situación provocó al poder filipino en Portugal, véanse asimismo algunas de las cartas enviadas a $\mathrm{D}$. Pedro de Castilho, presidente del Desembargo do Paço, por el cardenal Alberto, que, a pesar de haber abandonado ya el reino portugués, mantenía su cargo de legado pontificio; BA, cód. 51 -VIII-12, docs. 9 y 30. Véase además una misiva del propio D. Pedro de Castilho a Felipe II, en la que planteaba una serie de dudas al monarca sobre el trato y consideración que se debía tener en la mesa del Desembargo con el arzobispo, en el caso de que éste finalmente compareciese ante el tribunal regio; BA, cód. 51-VIII-7, doc. 60 .

49 El capítulo en cuestión, recogido posteriormente en las Ordenações filipinas (1603), en Ordenaçōes manuelinas, Liv. II, cap. $1, \S 1$. Véase al respecto HESPANHA, António Manuel: Visperas del Leviatán. Instituciones y poder político (Portugal, siglo XVIL), Madrid, Taurus, 1989; pp. 260. En relación con las polémicas y dudas que dicho capítulo suscitó, tanto en el reinado de Juan III, por denuncia del nuncio Lippomano, como durante el reinado de Sebastián I, cuando éste planteó a Gregorio XIII una serie de dudas de conciencia con respecto a las leyes del reino y su compatibilidad con la bula In coena domini, véase, AlmeIDA, Fortunato de: História da Igreja em Portugal, vol. II, pp. 312 y 334 . El arzobispo, de hecho, ya había suscitado anteriormente esta cuestión ante el propio Felipe II, durante la estancia que realizó en la corte de Madrid, en 1591; cfr., Memoria do que pasou o Arcebispo com S.M. e seus ministros sobre a ley de portugal e da ida a Roma e de outras cousas, Biblioteca Pública e Arquivo Distrital de Évora (=BPADE), cód. CIX/2-8, $\mathrm{n}^{\text {s. }}$. 76-78 y 80. 
cia eclesiástica ${ }^{50}$; finalmente, la expedición de un breve, de 2 de agosto de 1594, en el que el pontífice se quejaba ante Felipe II de los excesos que se cometían en el reino contra las libertades de la Iglesia ${ }^{51}$.

En realidad, más que como una simple respuesta frente a un ataque contra la inmunidad eclesiástica, este género de conflictos debe ser encuadrado, como apuntábamos, dentro de las lógicas de la práctica política de una época en la que la defensa de la jurisdicción no hacía sino traducir la necesidad de salvaguardar la propia capacidad en el ejercicio del poder. En este sentido, no se debe desdeñar el importante papel que la acción de los obispos tuvo en el propio disciplinamiento de los fieles, y, por consiguiente, la repercusión que dicha actividad, como ya señalamos, tenía sobre las poblaciones del Antiguo Régimen. A pesar de episodios de desencuentro como el que enfrentó a $\mathrm{D}$. Teotónio con el poder regio o como el que se desencadenaría en torno a 1595, con motivo de la contribución solicitada por Felipe II a los obispos portugueses para la construcción de un nuevo puente en la ciudad de Coímbra ${ }^{52}$, el poder episcopal fue un elemento insustituible en la política confesional filipina, tal como venía siéndolo desde mediados del siglo XVI. En el interés de la Monarquía de Felipe II y de su afianzamiento en el nuevo reino, por consiguiente, se encontraba no sólo controlar la jerarquía diocesana portuguesa, como facilitar o, al menos, no impedir el desarrollo de determinadas estrategias de afirmación de la autoridad episcopal, frente a otros actores que, dentro del ámbito diocesano, intervenían en el campo religioso, siendo, en ocasiones, un serio obstáculo para la actividad de los ordinarios ${ }^{53}$. En relación con esta cuestión, no está de más señalar la satisfactoria intermediación que algunos ordinarios portugueses consiguieron de Felipe II para la obtención y traslado a sus respectivas diócesis de las reliquias de aquéllos a quienes se atribuía la fundación de este o aquel obispado, con el

so Publicada en Gomes, Pinharanda: $O$ arcebispo de Évora dom Teotónio de Bragança (Escritos pastorais), Braga, Ed. do autor, 1984, p. 99. Sobre las reservas del poder filipino a la bula In coena domini y en relación con la forma de publicación de la misma en los territorios de la Monarquía Hispánica, véase, HerA, Alberto de la: «La bula in coena domini. El derecho penal canónico en España y las Indias", en MARTïnez Ruiz, Enrique, y PI CORRAles, Magdalena.de Pazzis eds., Instituciones en la España moderna, vol. II: Dogmatismo e intolerancia, Madrid, Actas, 1997, pp. 71-87.

s1 Clemente VIII, Breve Clamor gravium (2 de agosto de 1594), en Corpo Diplomático Portuguez, t. XII, pp. 57-60.

52 Una copia de la carta que, sobre esta cuestión, Felipe II mandó en 1595 al obispo de Coímbra, al igual que al resto de los prelados portugueses, en BRANDÃo, Mário: D. António Rei de Portugal, vol. III, pp. 109-110. La cuestión estaba aún pendiente dos años después, por la negativa de los ordinarios a contribuir para esta obra sin que mediase el acuerdo papal al respecto. La opción que el monarca se planteaba, si persistía la oposición de los diocesanos, era la de enviar a sus oficiales a las distintas parroquias del reino para recaudar directamente la contribución; Pedro de Castilho, Carta a Felipe II (Lisboa, 8 de agosto de 1597), BA, cód. 51-VIII-17, doc. 18.

53 Aunque referido al ámbito italiano, es de particular interés, desde esta perspectiva, el análisis de TORRE, Angelo: «Il vescovo di Antico Regime: un approccio configurazionale», Critica storica, 31 (1996), pp. 199-216.

Hispania, LXIV/1, núm. 216 (2004) 63-94 
claro propósito de, por medio de las mismas y de su culto, subrayar simbólicamente la figura y el poder del diocesano, tal como las directrices trindentinas, por lo demás, preconizaban ${ }^{54}$. Con todo, junto a este tipo de gestos, durante el reinado del primer Habsburgo portugués encontramos otro tipo de iniciativas episcopales de mayor calado institucional, desarrolladas aparentemente sin cualquier obstrucción del poder regio. Si, como ya indicamos, las celebraciones conciliares y sinodales que, en casi todos los obispados y provincias eclesiásticas, tuvieron lugar tras la clausura del concilio de Trento respondían a la necesidad de incorporar los decretos establecidos en dicha asamblea a la legislación y realidades diocesanas, dando lugar, en muchos casos, a la elaboración de nuevas constituciones sinodales y provinciales, una fase posterior, sin embargo, trajo consigo todo un proceso de redefinición y adaptación de las estructuras episcopales de gobierno, mediante el cual materializar, desde le punto de vista administrativo e institucional, ese pretendido fortalecimiento de la autoridad del obispo dentro el espacio diocesano. Este fenómeno de reorganización burocrática, que, en el caso de las diócesis españolas, parece haber tenido lugar en esos mismos años de finales del siglo XVI y durante el XVII, se plasmó en una serie de textos normativos o regimentos, por medio de los cuales se regulaba el funcionamiento y competencias de los diferentes tribunales y oficiales de las curias o auditorios episcopales. Los reglamentos de Oporto (1585), Funchal (1589), Coímbra (1591), Leiría (1598) o Évora (1598), por citar apenas lo que se elaboraron entre 1580 y 1598 , ponen de manifiesto una voluntad de modernizar y fortalecer los aparatos burocráticos dependientes del obispo, mediante la concentración de competencias en figuras como el vicario general y el provisor, que surgen como depositarios de la jurisdicción espiritual y temporal del ordinario y, por consiguiente, como figuras principales en el funcionamiento de la justicia y de la administración diocesanas, frente al peso que en épocas

54 Fue el caso del traslado de unas reliquias de San Mancio, primer obispo de Évora, al arzobispado eborense, en 1591. La obtención de las mismas, que se conservaban en el monasterio benedictino castellano de San Mancio, se debió al propio Felipe II, que, a petición del arzobispo D. Teotonio, intercedió ante el abad de Sahagún para que las referidas reliquias fuesen trasladadas a Évora. Sobre esta cuestión, véanse algunas relaciones y actos notariales de la cesión, autentificación y traslado de las reliquias en BNL, cód. 146, fols. 17-22v; Arquivo do Cabido da Sé de Évora, docs. EE-22-f, EE-22-g y EE-22-j. Esta práctica de reafirmación simbólica de la figura del prelado diocesano mediante el «descubrimiento" o traslado de las reliquias de quien, en la Antigüedad cristiana, había sido el primer obispo fue común a finales del siglo XVI, siendo el ejemplo más conocido el de las reliquias de San Ambrosio en Milán. Sobre el fenómeno del culto de reliquias en la península Ibérica durante el período moderno, véase: BOUZA ÁLVAREZ, José Luis: Religiosidad contrarreformista y cultura simbólica del Barroco, Madrid, CSIC, 1990. En concreto, para Portugal, cabe referir los estudios recientes de MARQUES, João Francisco: "Os itinerários da santidade: milagres, relíquias e devoções», en AZEvEDO, Carlos Moreira dir., História Religiosa de Portugal, vol. II, pp. 359-365; y de CARVALHO, José Adriano de Freitas: «Os recebimentos de relíquias em S. Roque (Lisboa 1588) e em Santa Cruz (Coimbra 1595). Relíquias e espiritualidade. E alguma ideologia», Via spiritus, 8 (2001), pp. 95-155.

Hispania, LXIV/1, núm. 216 (2004) 63-94 
anteriores habían tenido otras instancias como los cabildos ${ }^{55}$. Se procede igualmente -y en relación directa con el ejercicio de la justicia episcopal-al desarrollo de instrumentos adecuados para lograr un mejor control del territorio (de las fábricas eclesiásticas, de los agentes parroquiales y de los fieles). Con este objetivo, se definen, por un lado, las competencias atribuídas a toda una serie de oficiales (arciprestes y vicarios foráneos), que se vinculan estrechamente a la autoridad del prelado y que, a modo de red periférica, ejercen un control regular sobre la vida religiosa y moral del clero y la sociedad ${ }^{56}$; por otro, se crean instancias y cargos, dentro de las curias diocesanas, encargados específicamente de organizar y desarrollar anualmente visitas pastorales por diferentes partes del obispado. El recurso sistemático a las mismas, siendo que su práctica fue expresamente encomendada en Trento como parte integrante de las obligaciones del prelado, es un excelente indicio de la repercusión que el gobierno episcopal tuvo sobre las sociedades católicas del período moderno y, en particular, sobre las poblaciones portuguesas, sometidas así a un mecanismo complementario de las acciones desarrolladas por otras instancias, como el Santo Oficio, dado el carácter jurídico que la visita pastoral asumió en Portugal y de las

s5 No habiendo sido particular objeto de estudio entre los historiadores ibéricos, las estructuras burocráticas diocesanas, con todo, han merecido en los últimos tiempos alguna atención, tanto en lo que a su organización se refiere, como a la actuación de las mismas. Para el caso portugués, además de PaIVA, José Pedro: "A administração diocesana e a presença da Igreja. O caso da diocese de Coimbra nos séculos XVII e XVIII", Lusitania Sacra, $2^{a}$ série, 3 (1991), pp. 77-110; id., «Burocracia e organização eclesiástica», en AzEvedo, Carlos Moreira dir., História Religiosa de Portugal, pp. 187199, nos permitimos remitir a nuestro trabajo, ya citado, «La autoridad de los prelados tridentinos y la sociedad moderna. El gobierno de don Teotonio de Braganza en el arzobispado de Évora (15781602)», pp. 593-607. Para el caso de España, son de notar los trabajos de PÉrez-Prendes, José Manuel:, «El tribunal eclesiástico (sobre el aforamiento y la estructura de la Curia diocesana de justicia)», en MARTínez Ruiz, Enrique, y PI CORRALES, Magdalena de Pazzis, eds., Instituciones en la España moderna, vol. I: Las jurisdicciones, Madrid, Actas, 1996, pp. 143-169; BENLLOCH POVEDA, Antonio: «Jurisdicción eclesiástica en la edad moderna: el proceso», ibidem, pp. 113-142; PÉREZ MUÑOZ, Isabel: Pecar, delinquir y castigar. El tribunal eclesiástico de Coria en los siglos XVI y XVII, Cáceres, El Brocense-Excma.Diputación Provincial, 1992; CANDAU CHACón, María Luisa: «Delito y autoridad eclesiástica en la Sevilla de Carlos III", en Coloquio Internacional Carlos III y su Siglo. Actas, vol. II, Madrid, Universidad Complutense, 1990, pp. 183-197; GUTIÉRREZ GARCÏA BRAZALES, M.: «El Consejo de la Gobernación del Arzobispado de Toledo", Anales Toledanos, 16 (1983), pp. 63-138.

56 PALOMO, Federico: «La autoridad de los prelados postridentinos. y la sociedad moderna. El gobierno de don Teotonio de Braganza en el arzobispado de Évora (1578-1602)», págs. 603-607; CRESPO, Víctor, y GALÁN CAVILLA, José Luis: «La iglesia rural madrileña. Organización y control religioso (siglos XVI y XVII)», en MADRAZO, S., y PINTO, V. eds, Madrid en la época moderna. Espacio, sociedad y cultura, Madrid, Universidad Autónoma de Madrid-Casa de Velázquez, 1986, pp. 69-95. Para Italia, donde este tipo de oficialidad periférica ha merecido mayor atención, cabe destacar: ZARDIN, Danilo: "Et subito eseguirò quanto la mi ordini”. Contesto locale, vicari foranei e curia arcivescovile di Milano sul finire del Cinquecento", en La città di Angera, feudo dei Borromeo (sec. XVXVIII), Garivate, Nicolini, 1995, pp. 253-289; y TURCHINI, Angelo: «Officiali ecclesiastici fra centro e perifieria. A proposito dei vicari foranei a Milano nella seconda metà del XVI secolo", Studia borromaica, 8 (1994), pp. 153-213.

Hispania, LXIV/1, núm. 216 (2004) 63-94 
ya referidas capacidades de los ordinarios lusos para actuar sobre un número importante de delitos llamados de foro mixto ${ }^{57}$.

Para comprender la posición de la Corona frente a este proceso de reorganización burocrática y de afirmación del poder episcopal dentro del espacio diocesano, es necesario tener presente las propias concepciones de la época en torno a la constitución política de la sociedad. En realidad, frente a las tradicionales visiones «estatalistas» de la misma, un paradigma corporativo hacía que la autoridad regia, ocupando una posición preeminente dentro del campo político, se viese, sin embargo, confrontada con una pluralidad normativa y con la presencia de cuerpos políticos autónomos ${ }^{58}$. En este contexto, la capacidad jurisdiccional de la Iglesia y las bases de organización burocrática con las que contaba el poder diocesano portugués permitieron que éste desempeñase un papel esencial, no ya en el disciplinamiento moral y religioso de los fieles, sino como autoridad dentro de ámbitos periféricos en los que la presencia de la Corona era en muchas ocasiones más débilis9. En definitiva, el obispo —en Portugal como en otros territorios de la Europa católica- acabó ejerciendo una función, en cierta medida, subsidiaria de la propia autoridad regia, allí donde ésta se mostraba más frágil, ocupando en buena medida una posición privilegiada en la comunicación entre el centro (el monarca) y la periferia de los

57 En relación con las visitas pastorales en Portugal y su singularidad, de naturaleza jurídica, frente a los procedimientos utilizados en otros territorios de la Europa católica, además del estudio ya citado de Joaquim Ramos CARvalloo, es imprescindible la consulta de CARvalHo, Joaquim Ramos, y PAIVA, José Pedro: "A evolução das visitas pastorais na diocese de Coimbra nos séculos XVII e XVIII", Ler história, 15 (1989), pp. 29-41; PAIVA, José Pedro: "Uma instrução aos visitadores do bispado de Coimbra (século XVII?) e os textos regulamentadores das visitas pastorais em Portugal», Revista de História das Ideias, 15 (1993), pp. 637-661; id., "As visitas pastorais», en AzEVEDO, Carlos Moreira dir, História Religiosa de Portugal, vol. II, pp. 250-255; id., «La réforme catholique au portugal: les visites pastorales des évêques», Arquivos do Centro Cultural Calouste Gulbenkian, 43 (2002), pp. 159-175. Sobre la complementariedad entre la acción inquisitorial y las visitas pastorales en Portugal, véase, asimismo, PAIVA, José Pedro: «Inquisição e visitas pastorais. Dois mecanismos complementares de controlo social?», Revista de História das Ideias, 11 (1989), pp. 85-102.

58 Una excelente visión de la cuestión de la constitución política del Antiguo Régimen, del problema historiográfico del «Estado moderno» y de la posición ocupada por el poder real dentro de esa constelación de poderes presente en las formas de organización política de las sociedades modernas, es la de HESPANHA, António Manuel: Vísperas del Leviatán, pp. 19-37. Es igualmente de particular interés la síntesis sobre los diferentes paradigmas políticos existentes en el Portugal de Antiguo Régimen y, en especial, en relación con el paradigma corporativo, el estudio ya citado de HespanHA, António Manuel, y XAvier, Ângela Barreto: «A representação da sociedade e do poder», passim.

59 Hespanha, António Manuel: «Centro e periferia nas estruturas administrativas do Antigo Regime», Ler História, 8 (1986), pp. 35-60; id., Vísperas del Leviatán, pp. 154-172. Una excelente visión de síntesis sobre el problema del centro político y las periferias en el ámbito de las Monarquías europeas durante la edad moderna, es la de GIL PUJOL, Xavier: «Centralismo ou Localismo? Sobre as relações entre Capital e Territórios nas Monarquias europeias», Penélope. Fazer e desfazer a História, 6 (1991), pp. 119-144.

Hispania, LXIV/1, núm. 216 (2004) 63-94 
territorios (parroquias y fieles) ${ }^{60}$, y pudiendo contribuir, en último término, a la creación de consensos político-religiosos.

En efecto, el episcopado portugués no dejó de ser partícipe, en ocasiones, de las propias estrategias regias de instrumentalización del discurso religioso en beneficio de los intereses políticos de la Corona. Ya durante la crisis sucesoria se dieron ejemplos significativos en este sentido, como fue el caso de la carta pastoral que, en 1582, publicó el arzobispo de Braga, D. João Afonso de Meneses, en la que se declinaba una vehemente defensa de la legitimidad de Felipe II, recordando a los fieles la obligación que tenían de reconocerlo como su señor natural e intimidando con las correspondientes penas a quienes contestasen la realeza del nuevo monarca ${ }^{61}$. Ciertemente, a la hora de comprender la iniciativa del prelado bracarense, conviene no olvidar el hecho de que la suya fue una de las primeras nominaciones episcopales realizadas por Felipe II en Portugal. Con todo, el papel de los obispos portugueses en favor de determinados proyectos políticos del poder representado por el nuevo monarca no se restringieron al período de la crisis sucesoria y a las diferentes intervenciones que, en ese momento, fueron necesarias para aplacar la contestación al candidato castellano. Un buen ejemplo de su intermediación entre la Corona y las poblaciones del reino, favoreciendo así la adhesión en torno a la figura de Felipe II y de su política, es la actitud que el episcopado mantuvo en 1588, cuando, en vísperas de la Armada de Inglaterra, acudió a la petición del monarca para que se celebrasen, en las diferentes iglesias de sus respectivas diócesis, las correspondientes ceremonias religiosas destinadas a encomendar a Dios el buen suceso de la expedición y para que «mouido o pouo desta maneira a maior deuasão, pessa tambem de Deus com maior uebemençia sua ajuda» ${ }^{62}$. El propio D. Teotónio de Braganza, que, como se ha señalado, no siempre aprobó las opciones del poder filipino en lo que a la jurisdicción eclesiástica se refiere, no dejó ahora de secundar el pedido del monarca y, por medio de una carta pastoral, convocó a todas las personas del arzobispado eborense, seculares y eclesiásticas, a participar en una oración colectiva que, durante cuarenta horas, debía celebrarse en las iglesias parroquiales y en los monasterios de la archidiócesis, con el objeto de que,

«[...] fosse Deos seruido por sua misericordia guiar e encaminhar tudo a sua maior gloria e exaltação de sua sancta fee, bem e amplificação e recuperação de

60 PRODI, Paolo: «Tra centro e periferia: le istituzioni diocesane post-tridentine», en BENZONI, Gino, y Pegrari, Maurizio eds., Cultura, religione e politica nelletà di Angelo Maria Querini. Atti del convegno di studi promosso dal Comune di Brescia in collaborazione con la Fondazione Giorgio Cini di Venezia (Venezia-Brescia, 2-5 dicembre 1980), Brescia, Morcelliana, 1982, pp. 209-223.

61 João Afonso de Meneses, Carta pastoral (Braga, 20 de diciembre de 1582), s.l.: s.n., 1582 (BNL, Res. 1119A).

62 Véase, por ejemplo, la carta que, en este sentido, Felipe II envió el 15 de febrero de 1588 al obispo de Coímbra, D. Afonso de Castelo-Branco, de la que retiramos la cita; Brandẽo, Mário: Coimbra e D. António Rei de Portugal, vol. III, p. 69.

Hispania, LXIV/1, núm. 216 (2004) 63-94 
sua Igreja; e por que se deixa bem considerar do aparato desta armada das grandes necessidades que a Christandade padece pollas continuas perseguições não somente dos Turcos e Infieis, mas tambem dos hereges, e a muita christandade e zello de sua Magestade, que o seu intento he dar algum socorro a alguma Igreja que esteja oppremida e tyrannizada, ou arrancar e desarreygar dalgumas prouincias os errores em que estam e plantar a nossa Sancta fe catholica, e ser neguocio este que tanto vai a todos em geral como christãos, e os que viuemos nestas partes muito mais, que se afastem e se alarguem de nos longe os enemiguos da crux de Christo, dos sacramentos, da Virgem gloriosa nossa senhora e de todos os santos, perturbadores da união da Igreja catholica Romana, e destruidores das Republicas e do politico gouerno dellas» 63 .

Las intenciones perseguidas por Felipe II aparecían así revestidas de defensa de la Cristiandad contra la tiranía de unos herejes que, por lo demás, fueron una amenaza continua para las costas portuguesas durante aquellos años. Se apelaba, de este modo, a una identidad católica «supranacional», pero, al mismo tiempo, estrechamente ligada a la propia identidad regnícola portuguesa ${ }^{64}$, con el fin de suscitar el asentimiento de las poblaciones hacia las iniciativas regias. No en vano, algunos episodios significativos de este período adquirieron significados similares y se vieron sustentados por discursos de naturaleza confesional que contribuían tanto a reforzar el poder filipino, como a deslegitimar un persistente partido antoniano que, definitivamente, se habría «entregado» a los brazos de los heréticos.

Así, además del impulso que con un particular valor político - de vinculación del reino portugués a la nueva dinastía y a su Monarquía - se dio al proceso de canonización de Santa Isabel, reina de Portugal e infanta de Aragón, otros episodios de carácter religioso fueron igualmente objeto de usos políticos en beneficio de la realeza austriaca. El recibimiento, en 1588, de la colección de reliquias que D. Juan de Borja ofreció a la iglesia jesuita de São Roque en Lisboa, por ejemplo, asumió una dimensión político-confesional evidente, no sólo por constituir, dentro del contexto portugués, uno de los primeros actos de este género que, como consecuencia de los propios objetos «celebrados» (en su mayoría, reliquias procedentes de Alemania), adoptaba un registro inequívocamente contrarreformista, sino también por la «apropiación» que de este acto haría el poder filipino, tanto por medio de la presencia del cardenal Alberto en las ceremonias, como por su posterior empeño en fijar y hacer circular la memoria escrita de un evento que, como afirmara el jesuita Inácio Martins en el sermón que pronunció para la ocasión, no era sino expresión del favor de Dios

63 Teotonio de Braganza, Carta pastoral (5 de marzo de 1588), BPADE, cód., CIX/2-7, n ${ }^{\circ} .42$ y 43.

64 En relación a esta cuestión, cabe citar los trabajos de SILVA, Ana Cristina Nogueira da, y Hespanha, António Manuel: «A identidade portuguesa», en MAtToso, José dir., História de Portugal, vol. IV, pp. 19-37; THOMAS, Luís Filipe, y ALVES, Jorge Santos: «Da Cruzada ao Quinto Império", en BETHENCOURT, Francisco, y CURTO, Diogo Ramada eds.: A memória da naşão, Lisboa, Sá da Costa, 1991, pp. 81-165. 
hacia la ciudad de Lisboa y de su voluntad de defenderla ${ }^{65}$. Una vez más, el peligro apóstata, materializado en las continuas agresiones inglesas, y la necesidad de luchar y defenderse del mismo se hacía presente en un acto de naturaleza religiosa, que contó además con una participación masiva de gentes venidas de todo el reino, sirviendo, en buena medida, de cimiento a la política europea de quien se presentaba y era reconocido como principal valedor de la Iglesia católica. Similar lectura, aunque con una dimensión propiamente interna, merecen algunas de las actitudes desarrolladas frente a determinados fenómenos de carácter profético que fueron surgiendo a lo largo del reinado. Si el conocido Memorial de Pero Roiz Soares, de tono anti-castellano, constituye, por la abundancia de registros en este sentido, un buen ejemplo de la importancia que podían llegar a asumir toda suerte de signos y fenómenos astrológicos en el funcionamiento del propio campo político ${ }^{66}$, conviene no olvidar que nos encontramos en una época en la que es frecuente la presencia de personajes, cuyo carisma y fama de santidad los hicieron acreedores de una autoridad profética que, en no pocas ocasiones, podía resultar una amenaza política o, por el contrario, un excelente sostén para el poder regio ${ }^{67}$. En este sentido, más allá de los falsos sebastianes y de una doctrina —el sebastianismo- de carácter mesiánico; que sólo comenzó a tomar cuerpo a finales del siglo $\mathrm{XVI}^{68}$, el caso más paradigmático, en

65 La memoria de este recibimiento se materializó, por orden del cardenal Alberto, en el escrito de CAMPOS, Manuel de: Relaçam do solenne recebimento que se fez em Lisboa às santas reliquias que se levaram à igreja de sam Roque da Companbia de Jesus aos XXV de Janeiro de 1588, Lisboa, António Ribeiro, 1588. A propósito de esta celebración, véanse los análisis, realizados desde perspectivas diferentes, del trabajo ya citado de CARVALHO, José Adriano: «Os recebimentos de relíquias em S. Roque (Lisboa, 1588) e em Santa Cruz (Coimbra, 1595). Relíquias e espiritualidade. E alguma ideologia", y de CURTO, Diogo Ramada: A cultura politica em Portugal (1578-1642). Comportamentos, ritos e negócios (Tesis doctoral), vol. I, Lisboa, Universidade Nova de Lisboa, 1994, pp. 92-101.

66 SOARES, Pero Roiz: Memorial, passim.

67 En relación con el fenómeno profético y sus implicaciones en el campo político durante el período moderno, la bibliografía comienza a ser ya abundante en lo que concierne al conjunto del espacio europeo. Para la península Ibérica, además del estudio de KAGAN, Richard L.: Los sueños de Lucrecia. Política y profecía en la españa del siglo XVI (trad. de Francisco Carpio), Madrid, Nerea, 1991, cabe destacar, para el contexto específico portugués, los trabajos de CARvalHo, José Adriano de Freitas: «Um profeta de Corte na Corte: o Caso (1562-1576) de Simão Gomes, o «Sapateiro Santo» (1516-1576)», en Espiritualidade e Corte em Portugal (Séculos XVI a XVIII), Oporto, Instituto de Cultura Portuguesa, 1993, pp. 233-260; id., «Un "beato vivo": o P. António da Conceição, C.S.J.E., conselheiro e profeta no tempo de Filipe II», Via spiritus, 5 (1998), pp. 13-51.

68 Siendo particularmente extensa la bibliografía sobre el sebastianismo, remitimos apenas a algunas de las interpretaciones más recientes, como son las de CURTO, Diogo Ramada: «O Bastião! O Bastião! Actos políticos e modalidades de crença, 1578-1603» en CENTENO, Yvette K. coord.: Portugal. Mitos revisitados, Lisboa, Salamandra, 1993, pp. 139-176; OtIVARI, Michele: «Note sul sebastianismo portoghese al tempo di Filippo II", Studi storici, 2/200, pp. 451-470; id., "Una propaggine italiana del sebastianismo portoghese: variazioni introno a un vecchio saggio e ad un libro recente», Annali della Scuola Normale Superiore di Pisa. Classe di Lettere e Filosofia, $4^{a}$ serie, 4 (1999), pp. 499-517; BERCÉ, Yves-Marie: Le Roi caché. Sauveurs et imposteurs. Mythes politiques populaires dans l'Europe moderne, París, Fayard, 1990.

Hispania, LXIV/1, núm. 216 (2004) 63-94 
el Portugal de la época, de los «usos» políticos que podían derivar de la actividad visionaria y de la imputada santidad de un sujeto, es el conocido episodio de la monja del convento dominico de la Visitación, en Lisboa.

Sin entrar a relatar un suceso que, de hecho, ha sido numerosas veces analizado, en virtud de la propia implicación que en el mismo tuvieron figuras tan señeras como Luis de Granada ${ }^{69}$, cabe, sin embargo, llamar la atención sobre el giro que, a partir de determinado momento tomaron algunas de las acusaciones vertidas contra la religiosa lisboeta. En realidad, de ser foco de la devoción de rústicos y nobles, incluido el propio cardenal Alberto, la monja dominica, tras la derrota de la armada invencible (en la que se significó por haber bendito los estandartes de las compañías portuguesas) y después de la condena inquisitorial por sus «fingimientos», pasó a ser asociada, en tanto que elemento perturbador del buen orden (en este caso religioso), a los grupos de oposición a Felipe II $^{70}$. Del mismo modo que la santidad en vida y las atribuidas profecías del lóio António da Conceição fueron aprovechadas para servir de apoyo al poder filipino ${ }^{71}$, en aquellos mismos años y, en buena medida, como consecuencia del caso de Maria da Visitação, surgen otros episodios de falsa santidad femenina que, en algunos casos, fueron expresamente asociados al partido antoniano, como sucedió con Maria Dias, arrestada y, posteriormente, denunciada a la Inquisición por el obispo de Coímbra, D. Afonso de Castelo-Branco. En efecto, en una misiva a los miembros del Conselho Geral do Santo Ofício, el prelado advertía de la familiaridad de esta visionaria con personajes reputados por haber defendido en el pasado el partido de D. António ${ }^{72}$.

En la actitud del ordinario conimbricense se adivina, no sólo el grado de colaboración que buena parte del episcopado portugués mantuvo con la Corona, como la acentuada sintonía que, en general, existió entre el poder diocesano y uno de los instrumentos principales de la política confesional que desarrolló el poder regio en Portugal, desde mediados del siglo Xvi: el Santo Oficio. En realidad, dicha sintonía - no falta, con todo, de episódicos desencuentros- habría de ser una constante en las relaciones entre el episcopado luso y las autoridades inquisitoriales, fruto, no sólo de una conformidad ideológica en lo que a la ortodoxia religiosa y su defensa se refiere (sobre todo en relación con la cuestión judeoconversa), sino también por la noțable circulación que se produjo entre los propios agentes de ambas instituciones, cuyas jerarquías a menudo construyeron

\footnotetext{
69 HuERGA, Álvaro: «Introducción» a GRANAdA, Luis de: Historia de Sor María de la Visitación y Sermón de las caidas públicas, Barcelona, Juan Flors, 1962; id., «La vida pseudomística y el proceso inquisitorial de Sor María de la Visitación», Hispania Sacra, 12 (1959), pp. 35-96 y 333-356.

70 Una revisión de la lectura política tradicional de este episodio, es la realizada por CURTo, Diogo Ramada: A cultura política em Portugal, vol. I, pp. 67-81.

71 Sobre este personaje y el aprovechamiento político de sus «profecías», véase el trabajo de Carvalho, José A. de Freitas: «Un "beato vivo": o P. António da Conceição, C.S.J.E., conselheiro e profeta no tempo de Filipe II», passim.

72 ANTT, Conselho Geral do Santo Ofício, Liv. 91, doc. 35.
} 
sus carreras en el ámbito inquisitorial y en el diocesano ${ }^{73}$. Tras un período inicial, entre 1536 y ca. 1575 de organización y desarrollo burocrático e institucional, que tuvo en el cardenal D. Enrique a su principal arquitecto ${ }^{74}$, el Santo Oficio portugués conocería, a lo largo de los reinados de Felipe II y de Felipe III, una etapa que ha sido calificada de "expansión plena» del aparato inquisitorial, durante la cual, sin que se produjesen alteraciones sustanciales a las líneas de actuación trazadas con anterioridad, se pusieron en marcha algunas iniciativas que se verían coronadas con la elaboración de un nuevo regimiento inquisitorial $(1613)^{75}$. Es en el ámbito de algunas de dichas iniciativas donde la actitud del episcopado portugués resultó fundamental a la hora de concretar los proyectos del Santo Oficio, patrocinados por los tres personajes. que sucesivamente ocuparon el cargo de inquisidor-mor en las últimas dos décadas del siglo XVI: D. Jorge de Almeida, arzobispo de Lisboa (1578-1585), el cardenal Alberto (1585-1593/96) y D. António Matos de Noronha, obispo de Elvas (1593/961600). La política inquisitorial de este período estuvo marcada por una progresiva uniformización de los estilos observados por los diferentes tribunales y una mejor definición de las competencias sobre determinados delitos, por los intentos de desarrollar instrumentos de control del territorio que facilitasen la actuación judicial y censora del Santo Oficio, y por la continuación de una política de persecución preferentemente centrada sobre la comunidad judeoconversa, que se movilizaría en los años finales del reinado de Felipe II, con el objeto de obtener del monarca un nuevo perdón general, concedido apenas en $1605^{76}$.

Si la visita de los tribunales inquisitoriales, ordenada por el cardenal Alberto en 1592 , constituyó un primer paso en esa homogenización de las prácticas procesuales observadas en los diferentes distritos del reino (Lisboa, Évora y Coímbra), es a raíz de la misma cuando se elaboraron algunas instrucciones no sólo orientadas a impedir la actuación de los inquisidores sobre determinados casos, como la blasfemia o aquellos delitos de hechicería que pertenecían a la jurisdicción diocesana ${ }^{77}$, como destinadas a garantizar una mejor articulación entre las visitas pastorales y las intervenciones inquisitoriales. En este sentido y con el objeto de garantizar el secreto que sustentaba la eficacia de las acciones

73 PAIVA, José Pedro: «Os bispos e a Inquisição portuguesa (1536-1613)», Lusitânia Sacra, $2^{\mathrm{a}}$ série, 15 (2003), pp. 43-76.

${ }_{74}$ Sobre el establecimiento del Santo Oficio en Portugal y los primeros tiempos de construcción de su arquitectura institucional y procesual, véase, en particular, BETHENCOURT, Francisco: La Inquisición en la época moderna. España, Portugal, Italia, siglos XV-XIX, Madrid, Akal, 1997.

75 MAGALHÃES, Joaquim Romero: «Em busca dos "tempos" da Inquisição (1573-1615)», Revista de História das Ideias, 9/2 (1987), pp. 191-228.

76 Ibidem.

77 Treslado da Visitação de 1592. Publicado en Joaquim Romero Magalhães, op. cit., págs. 215221 (la disposición relativa a los delitos de blasfemia y hechicería, en pág. 215). En relación con la actuación del epsicopado portugués sobre los casos de brujería, remitimos al excelente análisis de PaIVA, José Pedro: Bruxaria e superstição num país sem "cạ̧a às bruxas", 1600-1774, Lisboa, Notícias, 1997.

Hispania, LXIV/1, núm. 216 (2004) 63-94 
emprendidas por el Santo Oficio, el archiduque Alberto, en su calidad de inquisidor general, solicitaría en esa misma fecha a todos los prelados del reino su colaboración y la de sus oficiales para que se observasen determinadas cautelas a la hora de proceder contra quienes, durante el curso de una visita pastoral, fuesen denunciados por culpas pertenecientes al foro inquisitorial ${ }^{78}$. La respuesta de los ordinarios portugueses a este pedido no parece haber suscitado particulares objeciones, siendo en algunos casos manifiesta la adhesión de los mismos a los procedimientos que dictaba el Santo Oficio, como fue el caso del propio D. Afonso de Castelo Branco ${ }^{79}$. Con todo, la articulación entre el poder episcopal portugués y las instancias inquisitoriales se haría patente en relación con otros muchos aspectos y, en concreto, con respecto a esa política de expansión que caracterizó este período, durante el cual se comenzaron a dar algunos pasos -aún tímidos- en la creación de redes periféricas de oficiales, por medio de los cuales garantizar una mayor presencia de la Inquisición sobre el territorio ${ }^{80}$. A este propósito, más allá del aprovechamiento que, eventualmente, se hizo de las propias estructuras diocesanas (arciprestes y vicarios) para la organización de las redes de comisarios, es significativo el apoyo explícito que, en 1584, se pidió a los ordinarios portugueses para que nombrasen oficiales en los puertos, encargados de la inspección de barcos y de la entrada de libros prohibidos en el reino ${ }^{81}$, incidiendo así en la activa política de censura de la Inquisición portuguesa, que, en este sentido, recurrió a éste y otros procedimientos, como la elaboración y publicación de índices y edictos particulares, la visita a librerías y el ejercicio de revisión previa de las obras que se publicaban en el reino ${ }^{82}$.

78 La solicitud del archiduque, de hecho, pretendía evitar que los visitadores episcopales iniciasen cualquier procedimiento judicial y, en concreto, cualquier interrogatorio que involucrase tanto al denunciado como a eventuales testigos, siendo, en todo caso, el obispo quien actuase en ese sentido y garantizando la obligación del secreto, antes de remitir la causa al correspondiente tribunal de la Inquisición. Asimismo, se pedía que no se encarcelase a los sospechosos sin que hubiese indicios de que pudiesen sustraerse al juicio inquisitorial. Véase: Alberto de Austria, Carta a D. Pedro de Castilho, obispo de Leiría (Lisboa, 28 de julio de 1592), BA, cód. 51-VIII-8, doc. 50.

79 Sobre este particular y, en general, acerca de este prelado portugués y de su estrecha colaboración con los tribunales inquisitoriales, cabe referir el trabajo citado de PAIVA, José Pedro: «Os bispos e a Inquisição portuguesa (1536-1613)», pp. 48-53.

80 En relación con la implantación de las redes de comisarios y familiares de la Inquisición portuguesa, bastante más tardía y lenta que en el resto de la península Ibérica, véase, BETHENCOURT, Francisco: La Inquisición en la época moderna, pp. 75-84; TORRES, José Veiga: «Da repressão religiosa para a promoção social: a Inquisição como instância legitimadora de promoção social da burguesia comercial», Revista Crítica de Ciências Sociais, 40 (1994), pp. 109-135.

81 BETHENCOURT, Francisco: La Inquisición en la época moderna, pp. 258-259.

82 Ibidem, pp. 231-232 y 255-260. Además de las páginas que dedica esta autor a la actividad censora de la Inquisición portuguesa, sobre esta cuestión, véase igualmente, REIS, Maria Fátima dos: «Um livro de visitas a naus estrangeiras. Exemplo de Viana do Castelo (1635-1651)», en SANTOS, Maria Helena Carvalhão dos, ed.: Inquisiz̧ão, vol. II, Lisboa, Universitária Editora, 1989, pp. 709742; SÁ, Artur Moreira de, ed.: Índices de livros proibidos em Portugal no século XVI, Lisboa, INIC, 1983; REGO, Raul: Os índices expurgatórios e a cultura portuguesa, Lisboa, Instituto de Cultura e Língua 
Con todo, el problema judeoconverso fue, sin lugar a dudas, la cuestión que despertaría un mayor grado de consenso entre la jerarquía diocesana lusa de finales del siglo XVI y las autoridades inquisitoriales, como consecuencia del rigor ortodoxo que caracterizaría el catolicismo moderno, pero también de la progresiva reestructuración, desde mediados de la centuria, de las jerarquías eclesiásticas del reino, en función de la propia presencia e impacto de la actividad desarrollada por el Santo Oficio portugués ${ }^{83}$. La vehemente recusa de los prelados portugueses a la propuesta, lanzada en 1592 por el cardenal Alberto, de que se elaborase un catecismo específicamente orientado al adoctrinamiento de los conversos ${ }^{84}$, los avisos para que la Inquisición visitase determinadas regiones en las que se sospechaba que hubiese una importante presencia de judaizantes ${ }^{85} \mathrm{y}$, sobre todo, la movilización de la jerarquía diocesana portuguesa en vísperas del perdón general de 1605 , con el objeto de impedirlo ${ }^{86}$, son muestras expresivas de la postura adoptada a este respecto por la generalidad de las elites religiosas y eclesiásticas del Porcugal de finales del siglo XVI, que vieron en la actuación represora inquisitorial un instrumento indispensable para la consecución de la pretendida homogeneidad confesional del reino.

En definitiva, es en esta óptica de la confesionalización católica y de los trazos que la caracterizaron dentro del contexto portugués de la segunda mitad de la centuria de 1500 , donde cabe inscribir la política religiosa seguida por Felipe II en relación con las jerarquías eclesiásticas y religiosas de la Corona incorporada en 1581 a su Monarquía. A pesar de los numerosos aspectos que cabría abordar en torno a esta cuestión y siendo que, en las presentes páginas, apenas se ha pretendido esbozar algunos de los elementos que orientaron dicha política, todo parece indicar, sin embargo, que la estrategia del monarca estuvo caracterizada por la continuidad en el desarrollo de lo que habían sido las líneas de fuerza establecidas, con un marcado tenor confesional, por los últimos representantes de la dinastía de Avís. En este sentido, las condiciones que, a lo largo del siglo XVI, articularon las relaciones entre la Corona portuguesa y los diferentes grupos de poder religioso constituyeron la base sobre la cual asentaría la posición de la jerarquía eclesiástica portuguesa en las negociaciones de

Portuguesa, 1982; RÉVAH, I.S.: La censure inquisitoriale portugaise au XVle siècle, Lisboa, Instituto de Alta Cultura, 1960.

83 BeTHENCOURT, Francisco: La Inquisición en la época moderna, p. 458.

${ }_{84}$ Varias de las cartas de los obispos portugueses, escritas a propósito de esta cuestión, se encuentran en ANTT, Conselho Geral do Santo Ofício, Liv. 91, docs. 50, 51, 64, 69, 70 y 72.

85 Aunque para un período relativamente posterior, cabe señalar el papel que desempeñó el obispo D. Francisco de Meneses en la campaña represora que emprendió la Inquisición en la diócesis del Algarve, en la década de 1630; MAGALHÃES, Joaquim Romero: «E assim se abriu juidaísmo no Algarve", Revista da Universidade de Coimbra, 29 (1983), pp. 1-73.

86 En relación con el perdón general de 1605 y la movilización de la jerarquía eclesiástica portuguesa, véanse los estudios clásicos de AZEvedo, José Lúcio de: História dos Cristãos Novos Portugueses [1921], Lisboa, Livraria Clássica, 1975, pp. 149-170; y de CARo BAROjA, Julio: Los judíos en la España moderna y contemporánea, vol. I, Madrid, Istmo, 1986, pp. 359-369.

Hispania, LXIV/1, núm. 216 (2004) 63-94 
Tomar y, posteriormente, su peso en el espacio político del Portugal filipino. La elección del archiduque Alberto como virrey, tras la salida de Felipe II en 1583 , supuso el recurso a una fórmula que no se distanciaba de las ensayadas en el pasado por la propia monarquía portuguesa, situando a la cabeza del poder secular y eclesiástico del reino a quien, en su condición de miembro de la dinastía de Habsburgo y hombre de Iglesia, estaba en situación de acumular la función de representación del monarca con las no menos estratégicas de inquisidor general y legado pontificio. Los amplios poderes que, en esta última ocupación, el papa concedió al sobrino de Felipe II, dieron al nuevo monarca un margen de maniobra suficiente a la hora de suprimir la contestación a su candidatura, que había tenido una particular incidencia entre algunos grupos y miembros del clero, así como resortes extraordinarios - más allá de los instrumentos habituales - con los que poder controlar el gobierno de determinadas congregaciones religiosas y tutelar una poderosa jerarquía diocesana. A pesar de enfrentamientos episódicos, que no se pueden deslindar de lo que fue un aspecto recurrente en las relaciones entre la Corona y el poder eclesiástico durante el período moderno y que se deben interpretar, además, en función de las lógicas que, en la época, regían el ejercicio de la política, los obispos portugueses no dejaron de ser un instrumento fundamental en la propia legitimación y consolidación de la realeza de Felipe II. Dentro del marco de garantía de sus privilegios como cuerpo, establecido en un Estatuto de Tomar demasiado cercano en el tiempo para que pudiese sufrir alteraciones de peso, la jerarquía diocesana portuguesa no sólo continuó teniendo una presencia importante en las más altas instancias de gobierno del reino, como consiguió mantener una capacidad considerable de intervención sobre la sociedad, por medio del ejercicio de una justicia más amplia que la reconocida a los obispos castellanos, y mediante el desarrollo de estructuras y mecanismos burocráticos de gobierno y control del territorio, orientados a reforzar la propia autoridad de los ordinarios dentro del espacio diocesano. Esta presencia del poder episcopal, en realidad, hizo de los prelados lusos piezas esenciales a la hora de construir consensos en torno a la figura del nuevo monarca y de su política, especialmente allí donde los objetivos perseguidos por Felipe II permitían una mejor movilización de argumentos de carácter religioso, por medio de los cuales apelar a una identidad católica, que bien se podía ver amenazada por los peligros heréticos representados por las continuas incursiones de los aliados ingleses de $\mathrm{D}$. Antonio, bien encontraba toda suerte de tibiezas y sospechas en una comunidad judeoconversa, sometida a la acción que, bajo la mirada de la Corona y con el sostén decidido de los diocesanos, desarrollaban los tribunales inquisitoriales portugueses. 